\title{
Anticipated pharmacological role of Aviptadil on COVID-19
}

\author{
Tuhin Mukherjee ${ }^{1} \cdot$ Tapan Behl $^{2}$ D $\cdot$ Sanchay Sharma ${ }^{2} \cdot$ Aayush Sehgal $^{2} \cdot$ Sukhbir Singh $^{2} \cdot$ Neelam Sharma $^{2}$. \\ Bijo Mathew ${ }^{3}$. Jasleen Kaur ${ }^{1} \cdot$ Ratandeep Kaur $^{1}$ - Mayukh Das ${ }^{1} \cdot$ Lotfi Aleya $^{4} \cdot$ Simona Bungau ${ }^{5}$
}

Received: 21 May 2021 / Accepted: 24 November 2021 / Published online: 30 November 2021

(c) The Author(s), under exclusive licence to Springer-Verlag GmbH Germany, part of Springer Nature 2021

\begin{abstract}
Vasoactive intestinal peptide (VIP) is a neuropeptide that is produced by the lymphoid cells and plays a major role in immunological functions for controlling the homeostasis of the immune system. VIP has been identified as a potent anti-inflammatory factor, in boosting both innate and adaptive immunity. Since December 2019, SARS-Cov-2 was found responsible for the disease COVID-19 which has spread worldwide. No specific therapies or 100\% effective vaccines are yet available for the treatment of COVID-19. Drug repositioning may offer a strategy and several drugs have been repurposed, including lopinavir/ ritonavir, remdesivir, favipiravir, and tocilizumab. This paper describes the main pharmacological properties of synthetic VIP drug (Aviptadil) which is now under clinical trials. A patented formulation of vasoactive intestinal polypeptide (VIP), named RLF-100 (Aviptadil), was developed and finally got approved for human trials by FDA in 2001 and in European medicines agency in 2005. It was awarded Orphan Drug Designation in 2001 by the US FDA for the treatment of acute respiratory distress syndrome and for the treatment of pulmonary arterial hypertension in 2005. Investigational new drug (IND) licenses for human trials of Aviptadil was guaranteed by both the US FDA and EMEA. Preliminary clinical trials seem to support Aviptadil's benefit. However, such drugs like Aviptadil in COVID-19 patients have peculiar safety profiles. Thus, adequate clinical trials are necessary for these compounds.
\end{abstract}

Keywords COVID-19 $\cdot$ SARS-CoV-2 $\cdot$ RLF-100 Aviptadil $\cdot$ Vasoactive intestinal polypeptide $\cdot$ Macrophages

$\begin{array}{ll}\text { Abbreviations } \\ \text { RAS } & \text { Renin-angiotensin system } \\ \text { JG cells } & \text { Juxta glomerular cells } \\ \text { DCT } & \text { Distal convoluted tubule } \\ \text { ACE } & \text { Angiotensin-converting enzyme }\end{array}$

Responsible Editor: Philippe Garrigues

Tuhin Mukherjee and Tapan Behl contributed equally to this work.

Tapan Behl

tapanbeh131@gmail.com; tapan.behl@chitkara.edu.in

1 Guru Nanak Institute of Pharmaceutical Science and Technology, Kolkata, West Bengal, India

2 Chitkara College of Pharmacy, Chitkara University, Punjab, India

3 Department of Pharmaceutical Chemistry, Amrita School of Pharmacy, Amrita Vishwa Vidyapeetham, AIMS Health Science Campus, Kochi, India

4 Chrono-Environment Laboratory, UMR CNRS 6249, Bourgogne Franche-Comté University, Besançon, France

5 Department of Pharmacy, Faculty of Medicine and Pharmacy, University of Oradea, Oradea, Romania
ADH Antidiuretic hormone

ROS Reactive oxygen species

SARS COV Severe acute respiratory syndrome coronavirus

VIP Vasoactive intestinal peptide

COVID-19 Coronavirus disease-19

TMPRSS2 Transmembrane protease, serine 2

VPAC VIP binding receptor

PACAP Polypeptide-activating pituitary adenyl cyclase

NMDA N-methyl-D-aspartate receptor

GM1

TNF

HCL

CCL

$\mathrm{CC}$

MIP

CCR

CXCL

CXCR4

GAG

TH pathway
Monosialotetrahexosylganglioside

Tumor necrosis factor

Hydrochloride acid

CC chemokine ligand

Chemokine

Macrophage inflammatory protein

Chemokine receptor

CXC chemokine ligand

Chemokine receptor 4

Glycosaminoglycans

T-helper pathway 


$\begin{array}{ll}\text { CD8 } & \text { Cluster of differentiation } 8 \\ \text { TREG } & \text { T regulatory pathway } \\ \text { IL6 factor } & \text { Interleukin-6 factor } \\ \text { ICU } & \text { Intensive care unit } \\ \text { ARDS } & \text { Acute respiratory distress syndrome } \\ \text { I.V. } & \text { Intravenous } \\ \text { ECG } & \text { Electrocardiogram } \\ \text { ALI } & \text { Acute lung injury } \\ \text { PaO2 } & \text { Partial pressure of oxygen } \\ \text { FiO2 } & \text { Fraction of inspired oxygen } \\ \text { FDA } & \text { Food and Drug Administration } \\ \text { ED } & \text { Erectile dysfunction } \\ \text { GIT } & \text { Gastrointestinal tract } \\ \text { PAH } & \text { Pulmonary arterial hypertension } \\ \text { IND } & \text { Investigational new drug } \\ \text { AT II CELLS } & \text { Alveolar type 2 cells } \\ \text { ECMO } & \text { Extra corporeal membrane oxygenation }\end{array}$

\section{Introduction}

As per the National Institute of Health (NIH)/Food and Drugs Administration (FDA) classification, respiratory failure is one of the major hallmarks of COVID-19 (Li and Ma 2020). About $50 \%$ of cases are highly intensified due to lack of care and ventilation (Robert et al. 2020). Several lead molecules are trying to exhibit promising results in clinical trials, one among them being Aviptadil, which is currently in phase II/III of clinical trials, where its pharmacological actions against COVID are under investigation. Based upon some reliable information, it is now being used as inhaled dosage form since June 2020 (Scavone et al. 2020). Aviptadil is a synthetic form of human vasoactive intestinal polypeptide (VIP) (Mathioudakis 2021). This review reveals the established mechanism of action of Aviptadil, evidently supported by the significant amount of data, related to reliable clinical trials performed. The vasoactive polypeptide comes into consideration as it binds to VPAC1 receptors present in the pulmonary alveolar type II (AT-II) cells in the lungs. This binding history initiates the study related to the COVID-19 disease. AT-II cells make up only $5 \%$ of the epithelial cells in the lungs but are critical for oxygen transfer and surfactant production and are also responsible for the formation of alveolar type- 1 cell (Singh and Chaturvedi 2020; Moody et al. 2000; Mason 2020). ACE2 is a surface receptor that is present on type II cells, selectively attacked by the SARS-CoV-2 virus (Jia et al. 2005). A high amount of vaso-intestinal polypeptide is present in the lungs, and binding to the AT-II cells prevent NMDA-induced caspase-3 activity (Poduri et al. 2020). Activation leads to inhibition of IL6 and TNF $\alpha$ production (Tanaka et al. 2014). AT-II also helps in preventing pulmonary edema and regulates the production of surfactant (Han and Mallampalli 2015). Aviptadil acts as a barrier at the alveolar interface and protects the lungs from failure and other organs from being affected (clinicaltrials. gov 2021). In the phase II trial, there was an evident outcome against the COVID19 where five trials were conducted under the influence of the European Regulatory Authority (europa. eu 2021). Infusion of Aviptadil showed good results with some adverse effects including alterations in blood pressure, heart rate, and ECG (Lythgoe and Middleton 2020). Aviptadil has been found to exert beneficial effects in restoring functions in pulmonary hypertension, ARDS, and acute lung injury (Johnson and Matthay 2010). According to previous researches and recent clinical trials, it has been demonstrated that COVIDinduced pneumonitis can be treated with Aviptadil infusion with maximal intense care (Petkov et al. 2003). Co-morbidities including smoking status and cardiovascular complications lead to poor efficacy of Aviptadil (Chatila et al. 2008). In May 2020, the emergency use of remdesivir got authorized by the FDA, which was completely based upon superficial results, however not that significant; but on the other hand, Aviptadil is an effective and safe alternative (fda.gov 2021).

\section{Vasoactive intestinal peptide}

Vasoactive intestinal peptide (VIP) is a peptide hormone that is proteinaceous and consists of 28 amino acids (Iwasaki et al. 2019). VIP being a neuropeptide is synthesized and discharged by both immune cells and nerve endings, which is associated with both central and peripheral activities (Grant et al. 2006). VIP is released by NANC (nonadrenergic noncholinergic autonomic nervous transmitter) nervous system which is an inhibitory neurotransmitter. VIP binds with two of its receptors, VPAC-1 and VPAC-2, belonging to the class of G-protein-coupled receptors (GPCRs). VIP along with pituitary adenylate cyclase-activating polypeptide (PACAP) activates VPAC-1 and VPAC-2. VIP shows various physiological actions in the gastrointestinal tract and also gets involved with some pathological cascade there; intestinal contractility and cellular motility are exhibited by VIP action. Activation of VPAC-1 shows significant results in the colon when tested on mice and humans. In the case of rat ileum, it shows predominant effects in mucosal and submucosal layers. VPAC-1 activation also shows epithelial functions, mucus secretion, ion transportation, as well as cell proliferation. Being one of the utmost substantial neuropeptides of the human body, VIP has a marked expression pattern within the visceral respiratory parts as well as the nasal mucosa (Dérand et al. 2004) (Fig. 1).

\section{VIP production in body}

It is produced from multiple sites of CNS, salivary gland, PNS nerve endings, etc. and stored in the hypothalamic suprachiasmatic nucleus. VIP exerts control over the SCN, 


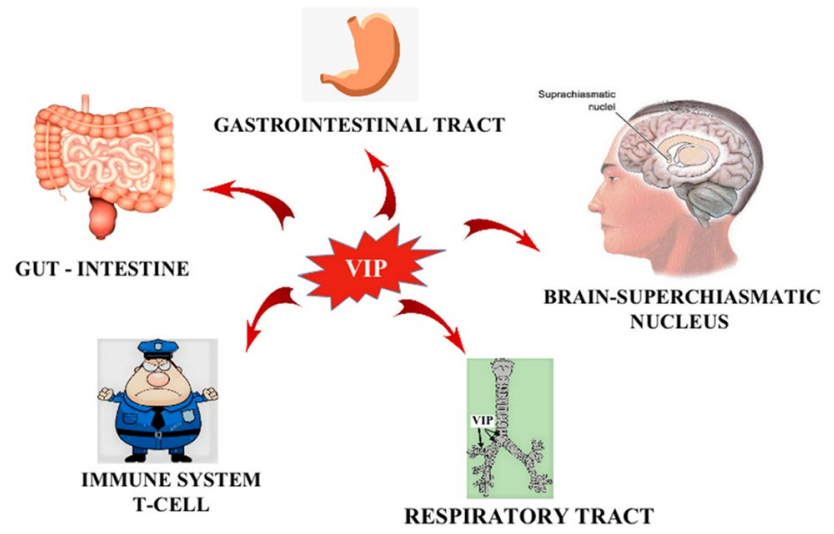

Fig. 1 Different pathological and physiological action of VIP on the gastrointestinal tract, intestine, immune cells, respiratory tract, and brain-suprachiasmatic nucleus. VIP helps in intestinal contraction and increases the motility of smooth muscles in GIT

which regulates circadian rhythm and gets stored in the hypothalamus which is internally synchronized (Achilly 2016). Optic chiasm is located just at the crossing over the region between two optic nerves, where VIP production and its localized action is seen (Ban et al. 1997). Similarly, the gastrointestinal tract (GIT) and pancreas produce VIP. During its release in the GIT, it acts on the chief cells and releases pepsinogen. When it acts on GIT, the basic function of VIP is to increase the motility of the smooth muscles. When the other muscles in GIT move faster than the sphincter muscle, it is said to be relaxed, and when they move slower than the sphincter muscles, it is said to be contracted (Prasse et al. 2010).

\section{Functions and uses of VIP}

In GIT, it relaxes the lower esophageal sphincter, gall bladder, and stomach, as well as increases secretion of water in the pancreatic juice, bile juice, and pepsinogen. It also reduces gastric acid secretion in the stomach (innerbody.com 2020). The main function of Aviptadil is observed in the alveolar sac in the lungs. Additionally, it causes coronary vasodilatation in CVS, thus reducing vaso-spasticity and lowering BP. On the other hand, it exerts ionotropic (increases heart contractions) and chronotropic (increases heart rate) effects, as a result of stimulation of $\beta_{1}$ adrenergic receptors. VIP thus is likely to play a major role in the vagal cardiac accelerator system (letstalkacademy.com 2020). Immunologically, Aviptadil in turn blocks the release of TNF $\alpha$ and IL-6. It causes a reduction in edema, which is caused by HCL. Aviptadil helps to generate $\mathrm{TH}_{2}$ and CD8 + cells, which are significant components of destructive immune response team, but it decreases the activation of CD4 + cells. It promotes the $\mathrm{TH}_{2}$ pathway as well as TREGS (Zhang and An 2007). Aviptadil is predominantly considered for application in COVID treatment since it impacts damaged cells in the respiratory system and strengthens the respiratory barrier. Aviptadil is an injectable form of a vasoactive intestinal polypeptide (VIP) in combination with adrenergic phentolamine (Lisi et al. 2020). It is mainly used in combination (phentolamine and with other drugs) for the treatment of erectile dysfunction. The major adverse effects like low BP and increased cardiac output is the only drawback reported (Steers 2020). As we know, Aviptadil is a synthetic peptide, so it is designed to minimize the adverse effects. VIP is expressed in the sex organs, both in males and females where it has been associated with sexual function (Azadzoi and Siroky 2010). It is also used to increase vaginal lubrication. It also regulates prolactin secretion from higher centers of the pituitary gland where prolactin secretion is responsible for milk production in mammary glands (Al-Chalabi et al. 2020).

\section{VIP activity in the respiratory system}

The key role of VIP is being conducted in the alveoli, as it exhibits homeostatic functions in the respiratory system (kidshealth.org 2020). The recent findings have reported its bronchodilatory and vasodilatory effects. It can induce housekeeping mucus secretion via submucosal origin. On the other hand, it has an immunomodulatory action as mentioned earlier, which includes humoral immune response suppression and remodeling of the bronchial environment, along with vascular and inflammatory attenuation. The gas exchange takes place in the alveolar wall, the blood carbon dioxide flows through the alveoli, and oxygen enters the blood vessels. This alveolus epithelium, connective tissue, and blood vessel endothelium together compose a membrane called the respiratory barrier. Aviptadil helps to hold the barrier and the corona virus aims to break it (Knudsen and Ochs 2018). In the alveoli, two types of cells are present, i.e., type-1 pneumocytes and type- 2 pneumocytes, where the latter is acted upon by Aviptadil. Vasoactive intestinal peptide exhibits affinity towards two receptors, where the first one is (VPAC-1R) generally called type-1 pneumocytes and the second one is (VPAC-2R) generally known as type-2 pneumocytes. VPAC-1 is mainly found in the liver, lungs, kidneys, mammary glands, spleen, lymphocytes, small intestine, and inner lining of the stomach. VPAC-2 is present in the smooth muscles of different organs and inside the vascular walls, adrenal medulla, and retina (Brandt and Mandiga 2020). 


\section{Type-2 pneumocytes}

Type-2 pneumocytes possess two receptors in them. The first one is the ACE 2 receptor, and the second one is the VPAC-1 or VIP-1 receptor. The viral affinity towards the ACE2 receptor is very high, and it destroys the respiratory barrier upon binding with it. On the other hand, VIP binds to the VPAC-1 receptor and protects the cell from destructive action of corona virus (Zhao et al. 2010). Type-1 pneumocytes are flat cells observed in almost 95\% of the total alveoli, and type- 2 pneumocytes are the bigger cells, constituting about $5 \%$ of the total alveoli. The role of type- 2 pneumocytes is to produce type-1 pneumocytes surfactant layer and oxygen transfer, as well as to maintain the respiratory barrier. The function of the surfactant layer is to reduce the surface tension within the alveoli and prevent them from collapsing (sciencedirect.com 2020). Hence, it is necessary to protect type- 2 pneumocytes because if they are damaged, then not only the part of the lung is damaged but the capacity to fix that part will be reduced due to lack of type- 1 cells. Aviptadil acts as a respiratory barrier and presents protective function. Lower doses of the drug induce bronchodilatation, while higher doses protect the respiratory barrier (Kia'i and Bajaj 2020) (Fig. 2).

\section{VIP impact on respiratory diseases}

Aviptadil shows its physiological and pathological action on respiratory diseases like asthma, COPD, cystic fibrosis, pulmonary arterial hypertension $(\mathrm{PAH})$, and sarcoidosis (Lindén et al. 2003). It has been observed that VIP has a crucial effect on the pathway that leads to PAH.

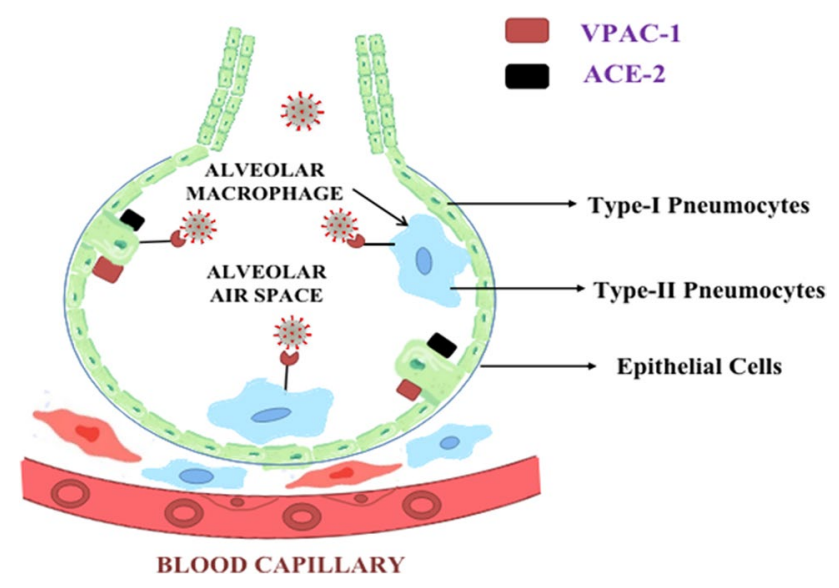

Fig. 2 Depiction of two types of pneumocytes present in the alveoli and type I and type II pneumocytes. VPAC-1 and ACE-II receptor present on type II pneumocytes. Type I pneumocytes, epithelial cells, and endothelium of blood vessels form the respiratory barrier
Diminished serum and pulmonary tissue levels have been observed in mice in the case of pulmonary arterial hypertension. On the other hand, elimination of the VIP gene causes a moderate or greater incidence of PAH (Morrell et al. 2013). In the clinical trials, Aviptadil initiated a mean pulmonary pressure decrement with an attendant expansion in the cardiovascular yield and blended venous blood oxygenation. Furthermore, later investigations depicted its immunomodulatory effects. At last, bronchial hyperactivity, optional to pre-capillary pneumonic hypertension, is likewise forestalled by VIP (Leuchte et al. 2008). There is not much evidence of study materials regarding the activity of VIP on sarcoidosis, but positive trial data regarding sarcoidosis is reported. It shows anti-inflammatory effects and reduces TNF activity. On the other hand, asthma, which is a persistent inflammatory disorder interceded by $\mathrm{Th}_{2}$ cells, TREGS, mast cells, eosinophils, neutrophils, along with the involvement of cells from the mesenchymal origin, like epithelial and endothelial cells, fibroblasts, and smooth muscle cells, get affected on a majority basis. Asthma is characterized by bronchoconstriction and immune reaction, so there is a mitigating effect of VIP on asthma. A pharmacological agonist of VIP might also additionally approach some other targeted therapy and will be suitable for patients, as corticosteroids and anticholinergics exhibit severe adverse effects (Spencer and Weller 2010; Qureshi et al. 2014). COPD is intervened with the Th1 pathway, which is not affected by the action of VIP. On the other hand, the Th2 pathway is downregulated by the action of VIP, which has been reported to inhibit the apoptosis of alveolar L2 cells caused by tobacco smokeinduced cytotoxicity, consequently preventing the development of the sickness (Wei and Sheng 2018). Mucous discharge within the lungs is brought about by acetylcholine and VIP, which act synergistically up to some extent. As far as physiology is concerned, this synergism is lost in cystic fibrosis; thus, VIP secretion is diminished in this case. Similarly, the response of submucosal organs to VIP is faded in patients with cystic fibrosis. Aviptadil causes an elevation in the CFTR level, with a threefold increment in Cl-efflux in bronchial epithelial cells (Saint-Criq and Gray 2017; Dasenbrook 2020).

\section{Introduction to SARS-CoV-2}

Coronavirus disease was identified in the year 2019 and hence was named the COVID-19 disease. The causative agent is the novel coronavirus, which is also known as severe acute respiratory syndrome coronavirus (SARSCoV-2). The World Health Organization declared COVID19 as a global pandemic. The virus was first identified in Wuhan (Hubei) in China, in December 2019. It was found 
in the respiratory tracts of the infected patients which were the indications of the new $\beta$ strain of coronavirus. Here, the detailed structure of SARS-CoV-2 is demonstrated along with its interaction with the receptor.

\section{SARS-CoV-2 structure}

SARS-CoV-2 is a non-segmented positive-sense singlestranded RNA (ssRNA) virus that is enveloped by a large number of glycosylated spike proteins, covering the surface of the virus (Singh et al. 2020). The SARS-CoV-2 virus is $29.9 \mathrm{~kb}$ in length, comprising of four main structural proteins, which are small envelope (E) glycoprotein, membrane (M) glycoprotein, nucleocapsid (N) glycoprotein, and spike (S) glycoprotein (Astuti and Ysrafil 2020). The N protein is the functional unit of the SARS-CoV-2 virus. It is located in the area of the endoplasmic reticulum-Golgi apparatus, structurally attached to the virus' nucleic acid material. As the protein is connected to the viral RNA, the protein is involved in processes, which include the viral genome and cycle of viral replication (McBride et al. 2014). The M protein has a very important role in determining the structure of the virus (Ghosh et al. 2021). It helps in stabilizing nucleocapsids and $\mathrm{N}$ protein-RNA complex within the inner virion, by which it facilitates the completion of the viral assembly (Neuman et al. 2011). The E protein plays a significant role in the production and maturation of the virus (Ruch and Machamer 2012). The S protein is a transmembrane protein of class 1 type of trimeric TM glycoprotein, which is responsible for the entry of the virus. The $S$ protein is the key factor for viral infection (Bosch et al. 2003). The trimeric part of $S$ protein is the basic unit for binding $S$ protein to the receptor. The $\mathrm{S} 1$ part of the $\mathrm{S}$ protein consists of the receptor-binding domain or RBD, which mainly helps in the binding process. The S2 part contains the HR domain which includes Heptad repeat or HR1 and HR2 and is responsible for the fusion of the virus with the cell membrane (Du et al. 2009) (Fig. 3).

\section{SARS-CoV-2 interaction with receptor}

The SARS-CoV-2 invasion into the pulmonary pathway mainly leads to the destruction of the respiratory barrier, which is composed of epithelial tissue, connective tissue, and the endothelium of the blood capillaries ( $\mathrm{Gu}$ and Korteweg 2007). The diffusion of $\mathrm{O}_{2}$ and $\mathrm{CO}_{2}$ occurs across the respiratory barrier; thus, any problem with the respiratory barrier will affect the respiratory process. Epithelial tissue has alveolar epithelial cells or pneumocytes which are of two types: type I and type II. SARS-CoV-2 binds to the type II pneumocytes, present in the walls of alveoli (Cardani et al. 2017). Type II pneumocytes have very crucial importance in the production of surfactant, type I pneumocytes, and most importantly oxygen transfer (Fehrenbach 2001). It mainly helps in maintaining the respiratory barrier (LeMessurier et al. 2020). Type II pneumocytes have angiotensin-converting enzyme 2 (ACE2) receptor which is responsible for viral attachment. SARS-CoV-2 needs to get activated before binding to the ACE2 (Zhang et al. 2020). Activation means exposure of the S1/S2 site of the viral S protein towards the receptor (Coutard et al. 2020). The type II transmembrane protease serine protein or TMPRSS2 is responsible for the activation of the SARS-CoV-2, alongside the viral S protein (Simmons et al. 2013), which facilitates viral entry. The $\mathrm{S}$ protein binds to TMPRSS2 for priming, which leads to $\mathrm{S}$ protein cleavage at the $\mathrm{S} 1 / \mathrm{S} 2$ site. Cleavage of the S1/S2 site exposes the receptor-binding protein located on the S1 part of the S protein. Along with TMPRSS2, Furin is also responsible for the activation of $S$ protein (Thunders and Delahunt 2020). The S1 part of the
Fig. 3 Structure of SARSCoV-2 showing the $\mathrm{N}$ protein, E protein, $S$ (spike) protein, and $\mathrm{M}$ protein. The $\mathrm{N}$ protein is the functional unit of the SARS$\mathrm{CoV}-2$ virus. The E protein plays an important role in the production and maturation of the virus. The $\mathrm{S}$ protein is a transmembrane type protein. It is a class 1 type of trimeric TM glycoprotein which is responsible for the entry of the virus. The $\mathrm{S}$ protein is the key factor for viral infection. The $\mathrm{M}$ protein has a very important role in determining the structure of the virus

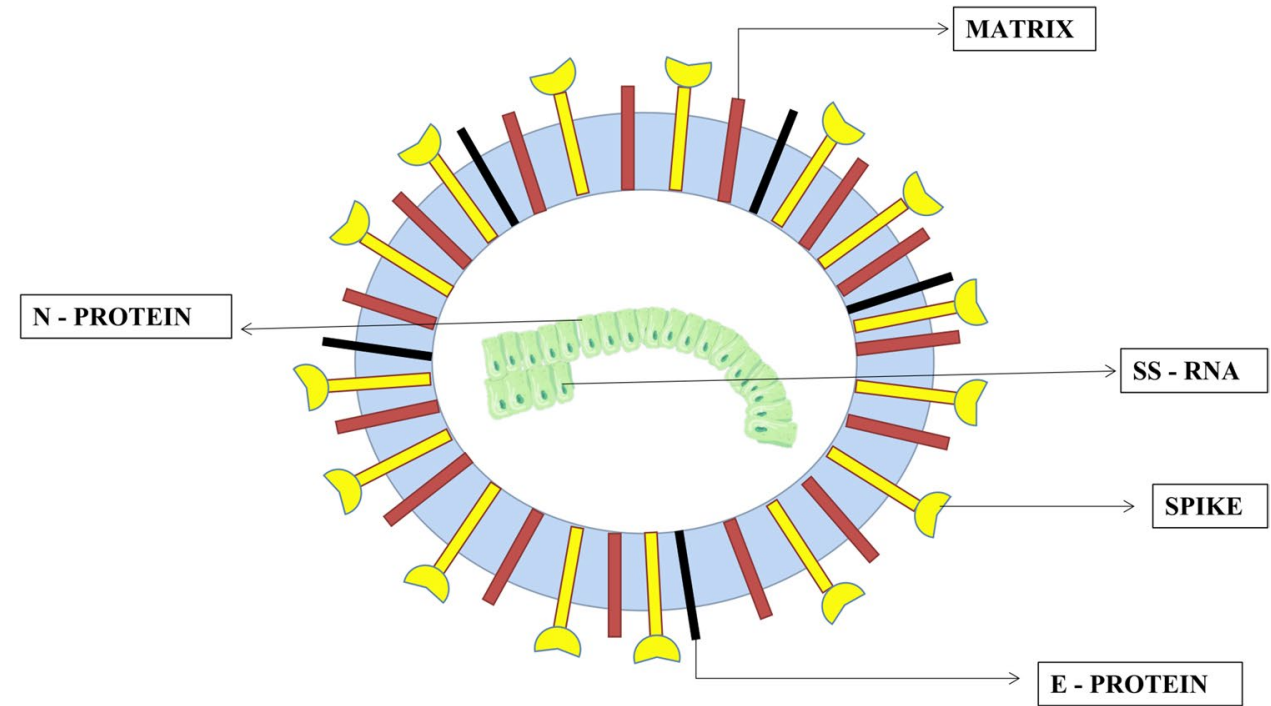


protein binds to the ACE2 receptor facilitating viral entry. The S2 part is related to the fusion of the viral membrane with the cell, further initiating viral infection. The SARS$\mathrm{CoV}-2$ also binds to the ganglioside type 1 (GM 1) receptor. The binding of SARS-CoV-2 to the ACE 2 receptor also causes damage to the significant cells of the immune system, like macrophages and dendritic cells (Tang et al. 2020). Entry of SARS-CoV-2 triggers the innate immune response which leads to the gathering of alveolar macrophages, differentiated from bone marrow-derived monocytes (Merad and Martin 2020), acting as the first line of defense. ADAM 17 , which is a metallopeptidase enzyme, acts as a shedding enzyme for the ACE2 receptor (Heurich et al. 2014). The shedding of the ACE2 receptor involves cleavage and release of the domain which attaches to the $\mathrm{S}$ protein of the virus. Viral infection promotes elevated immune response which can be pro-inflammatory (Wu et al. 2020) (Fig. 4).

\section{Immunological response on SARS-CoV-2 infection}

SARS-CoV-2 attaches to the cell by binding to the ACE2 receptor. The $S$ protein of the virus exhibits binding affinity towards the ACE2 binding domain. This results in the fusion of the virus with the healthy cells, resulting in the entry of viral RNA (Zhou et al. 2015). The infected cell machinery is used to produce more RNA by replication. In this process, cell lysis takes place. As the new viral cells are produced inside the infected cell, they break through the cell membrane to come out (Lodish et al. 2000). The NK or natural killer cells, which constitute the innate arm of the immune system, portray that the amount of protein on the membrane of the infected cell is not optimum, which further demonstrates that the cell is infected and the inside machinery is not working correctly (Vivier et al. 2011). A normal cell produces the major histocompatibility complex class 1 (MHC1) protein, which is identified by the NK cells, preventing healthy cells from the attack of NK cells (Paul and Lal 2017). On the other hand, the SARS-CoV-2 infected cells do not produce this complex protein, as their nucleus is not healthier; hence, the NK cells get activated, and further attacking those infected cells. The NK cells trigger NMDA-induced caspases which prepare the cell for the apoptotic pathway. Also, the NK cells release an enzyme called PERFORIN which makes a hole in the target cells and then sends granzyme which triggers the cell to undergo apoptosis (Topham and Hewitt 2009). Whenever a cell is infected by the virus, its cellular defense mechanism comes into action by releasing interferons, especially interferon $\beta$, which is a signal for the neighboring cells to become much stronger to resist the viral infection. The SARS-CoV-2 inhibits cellular defense mechanism. Viral protein prevents interferon production from the infected cells as the cellular machinery is hijacked (Frieman and Baric 2008). This makes the neighboring cells unaware of the situation happening close by and remains vulnerable to the viral attack. Infection in macrophages and dendritic cells by SARS-CoV-2 induces conformational changes in the membrane where antigen of viral origin is attached, thus acting as antigen presenting cells (APCs), which present themselves to naive T cell. In the presence of IL-4 or IL-13, T-helper 2 (Th2) cells are brought into vicinity, continuing $\mathrm{Th} 2$ pathway which is anti-inflammatory in action. On the other hand, IL-12 brings in Th1 cells exhibiting the Th1 pathway which, on the contrary, is pro-inflammatory in action (Bellinghausen et al. 2003). SARS-CoV-2 mostly enhances the pro-inflammatory action and secretion of more inflammatory molecules. This also leads to the increased production of cytokines and chemokines, viz., CXCL1, CXCL2, CCL3, CCL4, CCL5/RANTES, CXCL10, CXCL1, and
Fig. 4 Binding of SARS-CoV-2 with type II pneumocytes and macrophages, at ACE2 enzyme site using spike protein which is activated by TMPRSS 2 or furin present on the cells. The ACE2 enzyme is released by ADAM17 a metallopeptidase which will be available for binding process

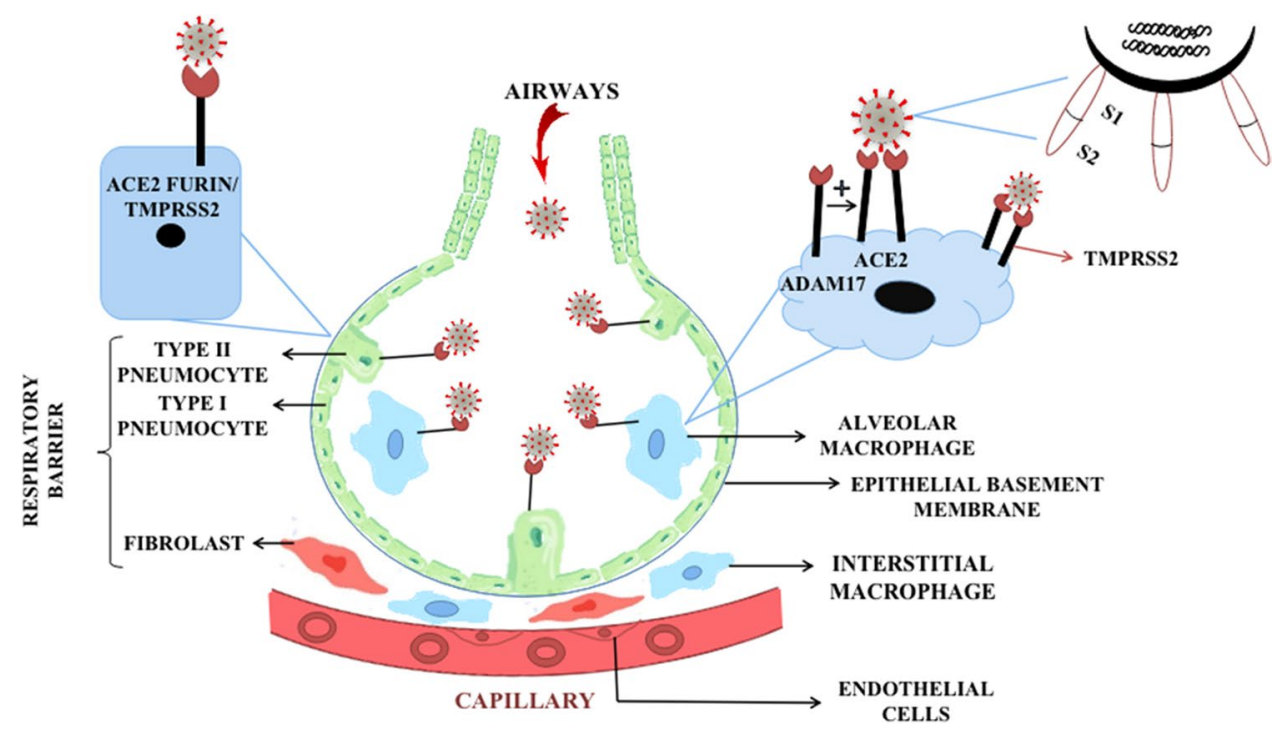


CXCL2 brings neutrophils, whereas CCL3, CCL4, and CCL5/RANTES brings in macrophages, monocytes and $\mathrm{T}$ cells. These chemokines act as signals for the macrophages, monocytes, and other immune cells to come over and support the process of inflammation. CXCL10 is the one that is responsible for cytokine storm. Despite the macrophages functioning as important antiviral agents, the presence of the ACE2 enzyme makes it a prey for SARS$\mathrm{CoV}-2$, therefore making the pulmonary parenchyma vulnerable to the viral attack (Coperchini et al. 2020) (Fig. 5).

\section{RAS pathway}

The RAS pathway is carried out by crucial cells termed the juxtaglomerular (JG) cells, which are renin secreting specialized smooth muscle cells (Gomez and Sequeira-Lopez 2018). Renin production is a result of low blood pressure; sympathetic nerves firing the JG cells during stress and signal from macula densa cells present in distal convoluted tubules (DCT) (Persson 2003; Peti-Peterdi and Harris 2010). During low blood pressure, the macula densa cells stimulate JG cells via prostaglandins, which act as local messengers (Sparks et al. 2014). Angiotensinogen, an inactive protein (485 amino acids long) produced by the liver cells is converted into an active protein angiotensin 1 (10 amino acids long) by renin (Nehme et al. 2019). The ACE 1 enzyme, which is present in the endothelial cells, converts angiotensin 1 to angiotensin 2 ( 8 amino acids long), which is a bit more active than angiotensin 1 . Angiotensin 2 causes the smooth muscle of the blood vessels to contract, thereby increasing resistance. It acts on the pituitary gland to release antidiuretic hormone (ADH), which increases resistance in the blood vessels, as a result of which the kidneys can retain more water (Benigni et al. 2010; Boone and Deen 2008). Angiotensin 2 also acts on the adrenal gland to release aldosterone which helps in retaining water and salts in the kidney. The interesting fact about the RAS system is that it starts and ends in the kidney (Lefebvre et al. 2019) (Fig. 6).
Fig. 5 A Viral RNA entry into the cell causes cell death due to rupture of the cell membrane and detection of NK cells due to absence of MHC-1 protein. NK cells release perforin which makes a hole in the cell and then releases granzymes causing apoptosis. B Viral infection inhibits the nucleus of the infected cell to release interferon $\beta$. C SARS-CoV-2 binding to macrophages and initiating the sequence of chemokine release and cytokine storm
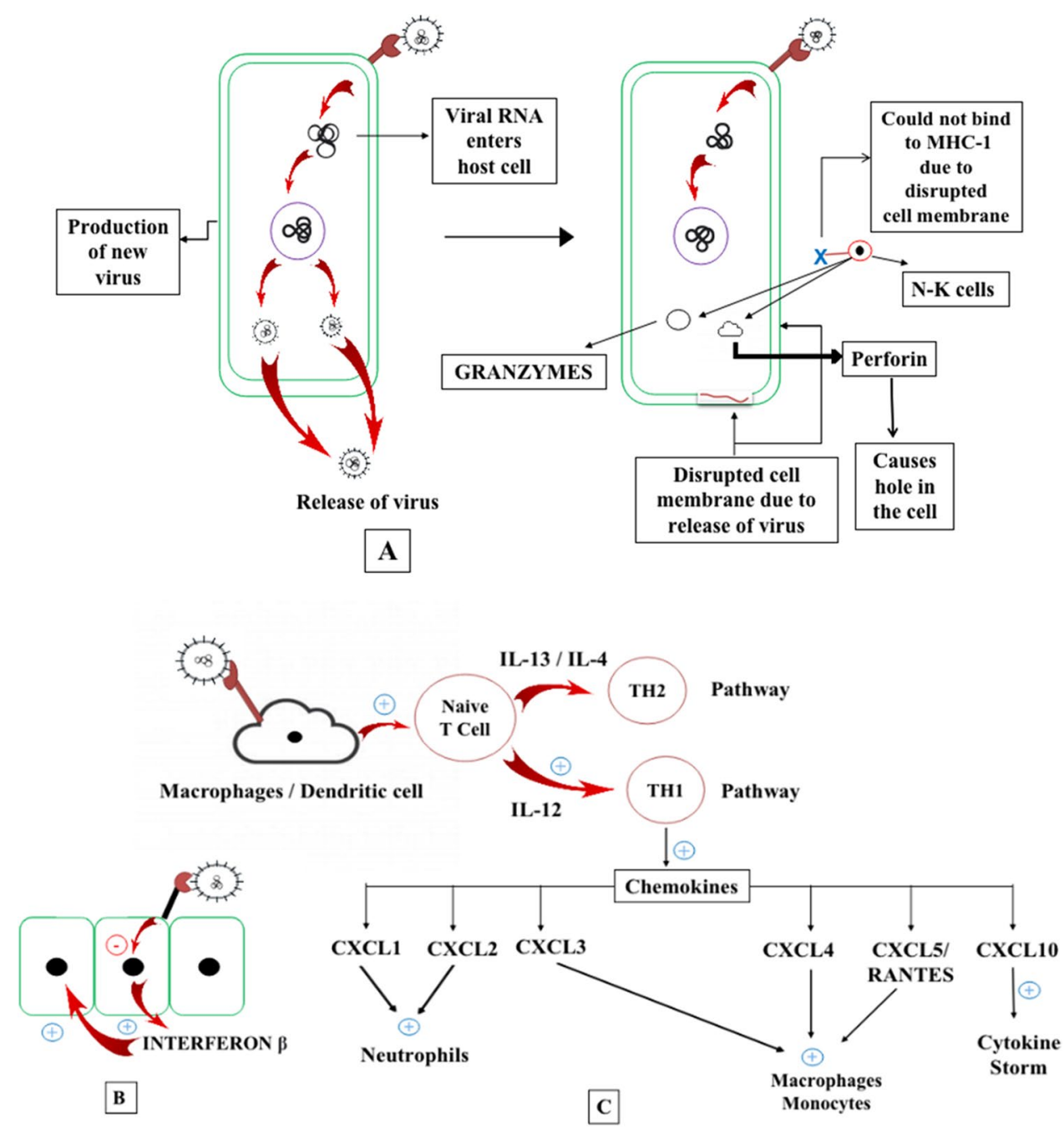


\section{ACE1/ACE2 balancing RAS}

As mentioned earlier, angiotensin 2 induces vasoconstriction, and, on the other hand, it is pro-inflammatory in nature (Brewster and Perazella 2004). Angiotensin 2 binds to AT1receptor and produces reactive oxygen species (ROS) inside the cell. The production of ROS is toxic, not only to the cell but also to its surrounding cells (Pendergrass et al. 2009). Once ROS is released from the cell, it starts damaging the surrounding cells, thus inducing trigger response to initiate macrophage action and bring them in the vicinity, further activating the immune system (Nita and Grzybowski 2016). Angiotensin 2 causes inflammation, apoptosis, and tissue remodeling, affecting mainly the pulmonary and cardiac tissues, thus requiring an optimum balance (Gheblawi et al. 2020). The action of the ACE2 enzyme is depicted below in the figure (Fig. 7).
ACE2 is a carboxypeptidase and is responsible for angiotensin 2 destruction (Clarke and Turner 2012). The catalytic ectodomain of ACE2 is released from the cells with the help of metalloprotease ADAM17, as discussed earlier (Jia et al. 2005). Angiotensin 1, in contrast to angiotensin 2, is a vasodilator and anti-inflammatory in action. Thus, the effects of the RAS pathway are balanced by both ACE1 and ACE2 enzymes (Donoghue et al. 2000).

\section{SARS-CoV-2 and RAS}

SARS-CoV-2 infection results in a major imbalance in the RAS pathway. It acts via two pathways viz. inhibition of ACE2 activity and reduction of ACE2 expression. Infection due to SARS-CoV-2 creates an imbalance between ACE1 and ACE2 products whereby increasing angiotensin 2 activity, resulting in vasoconstriction and pro-inflammatory

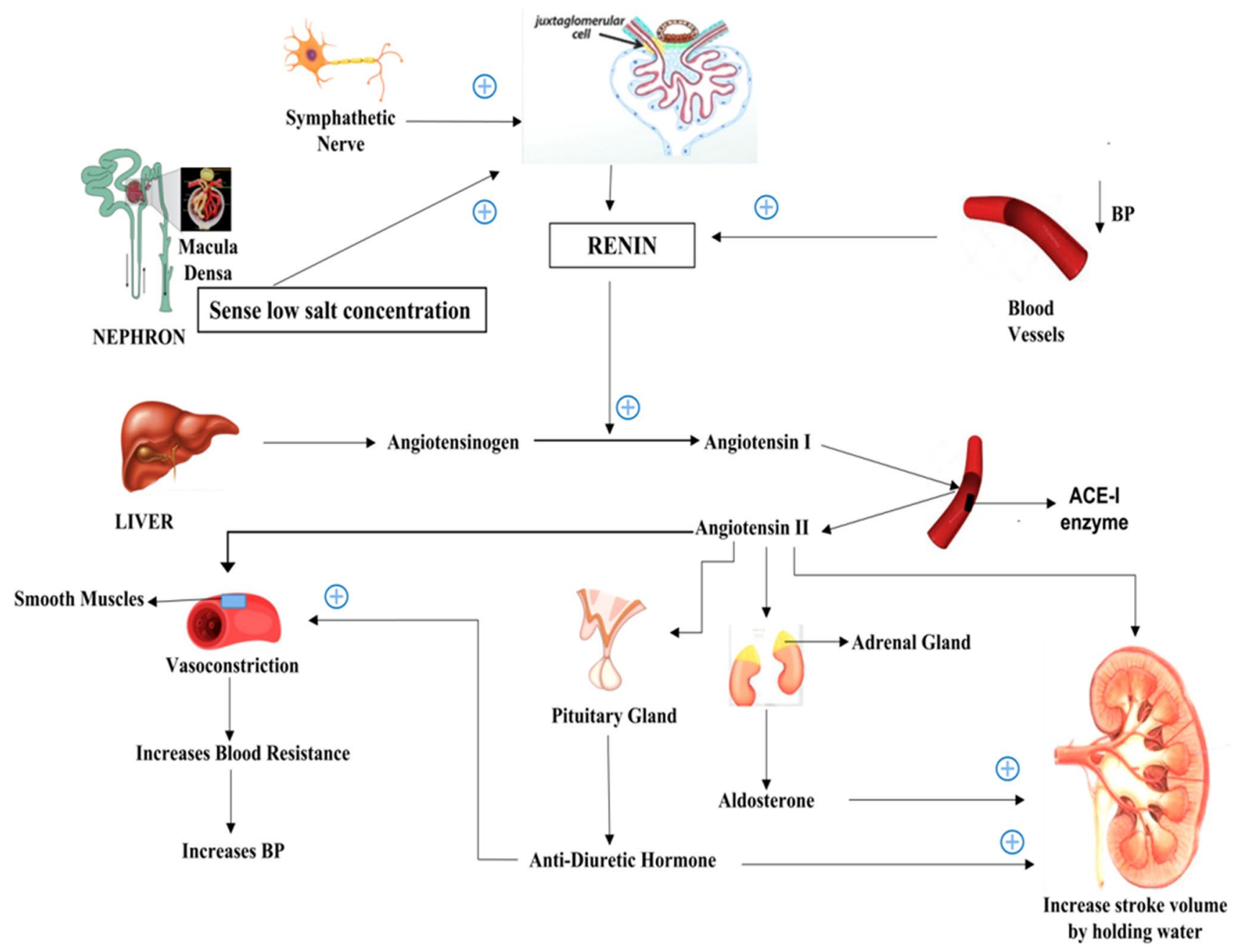

Fig. 6 RAS pathway showing how different stimuli like lowering in BP signals from sympathetic nerve and low salt concentration induces renin production which helps in converting angiotensinogen to angiotensin-I which is further converted to angiotensin-II by ACEII enzyme present in the endothelial cells of blood vessels 


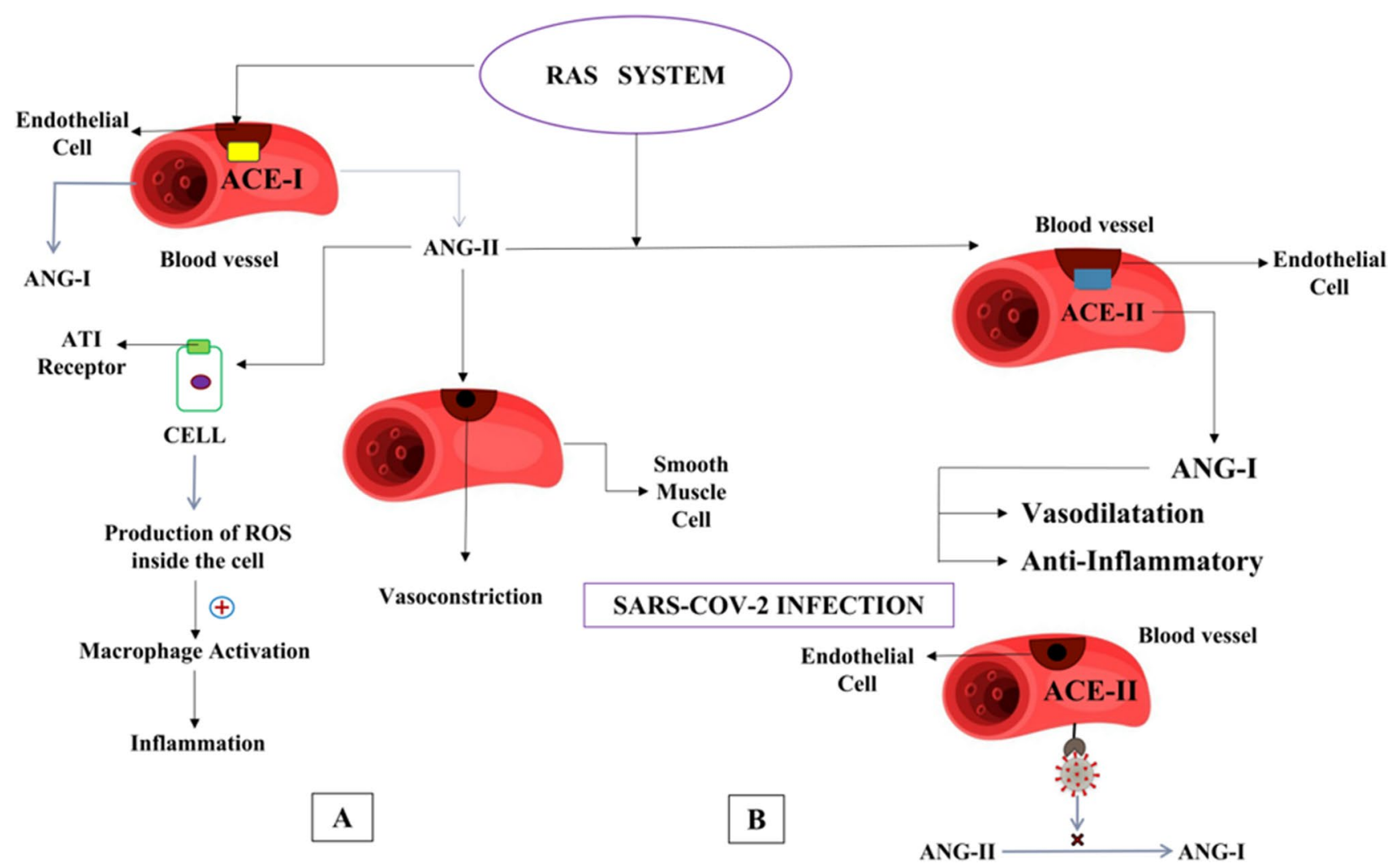

Fig. 7 A Balancing of RAAS system by ACE1/ACE2 enzyme by balancing the ratio of angiotensin-I and angiotensin-II concentration. B Imbalance of RAAS system caused by SARS-CoV-2 by binding to

ACE2 enzyme, hence inhibiting the conversion of angiotensin-II to angiotensin-I thereby promoting pro-inflammatory action

effects (Behl et al. 2020). As a result, blood pressure may be increased (Danilczyk and Penninger 2006). The immune response is enhanced by macrophage accumulation due to AT 1 signaling, which can elevate the viral infection. Patients who are more susceptible to angiotensin 2-associated damage and decreased activity of ACE2 enzyme during SARS virus infection can initiate a chain of injurious effects due to imbalance in ACE1 and ACE2 products (Benigni et al. 2009).

\section{Mechanism of action of Aviptadil}

Research on the physiological activity of VIP in respiratory therapy have demonstrated some important improvements in COVID-19 disease. Among several drugs of VIP, Aviptadil has the potential to act as a SARS-CoV caspase blocker (Busnadiego et al. 2020).

\section{Lung tissue receptors localization}

At first, the receptor localization of the SARS-CoV attacking site and Aviptadil attaching site is important to understand. Pulmonary alveolar epithelial cells contain Alveolar type

2 proteins, which are responsible for alveolar function and gas exchange. These proteins are also present in enterocytes, i.e., the cells responsible for contact with the external environment (Brosnahan et al. 2020). They secrete surfactant, a molecule that reduces the surface tension and contributes to the elastic properties of the lungs (Lewis and Jobe 1993). These cells have a high concentration of ACE 2 receptors on their membrane which is the entry point for the attachment of the virus, propagating infection in other human cells (Galanopoulos et al. 2020). On the other hand, type 2 cells also have TMPRSS2 protein, which is blocked by bromhexine and chemostat mesylate. Viral replication and rupture releases inflammatory cytokinin and destroys surfactant production (Shen et al. 2017). The activity of Aviptadil is mediated by type 1 VIP receptors (VPAC1) and type 2 receptors (VPAC2), which are both activated by polypeptide-activating pituitary adenyl cyclase (PACAP) (Martínez et al. 2019). VPAC1 is more abundant in lung tissues, whereas, on the other hand, VPAC2 is the most abundant in smooth muscles, mast cells, and the basal part of lung mucosa (Mathioudakis et al. 2013). Also, protein caspase, induced by NMDA cells, is present which performs programmed cell death when the virus gets attached (Parrish et al. 2013). Interestingly, the 
genes encoding inflammatory caspase are present nearby the human chromosome and murine chromosome where at first they are produced in inactive form as procaspase, in resting cells (McIlwain et al. 2013).

\section{Aviptadil action over caspase protein}

The first step in any viral infection is the binding of the virus to a host cell through the target receptor. SARS-CoV enters into the cells through interaction of viral spike or $\mathrm{S}$ glycoprotein in spike (a protein envelope of coronavirus characteristically round-headed and tall stalked morphology) with ACE2 enzyme present on type 2 pneumocytes (Mariappan et al. 2020). Here, TMPRSS 2 protein guides the $S$ protein to get connected with ACE2 where a part of the virus also gets connected with GM1 called ganglioside type (Hoffmann et al. 2020). The result of this attachment leads to the invasion of the virus into the cell and starts producing more viruses, resulting in cell lysis. This sick cell is discovered by natural killer cells or CD8 cells, which then instruct the cell to kill itself under the order of a protein known as caspase (Loiseau et al. 2020). Here, Aviptadil acts as a scavenger for cell. When Aviptadil gets attached to the VPAC1 receptor on the affected type 2 pneumocytes, the secondary mechanism inside the cell results in a blockade of response to caspases. As a result, cell death is prevented (Couvineau and Laburthe 2012). Aviptadil shows a protective mechanism by not only preventing cell death, but it also inhibits immune cells to produce TNF alpha and IL6 factor so that immune cells do not overreact (Kany et al. 2019). In addition to this, Aviptadil improves edematous condition induced by necrotic disorders, i.e., an acute respiratory distress syndrome, thus reducing piling up of fluids and providing protection to the lungs (Matthay et al. 2019) (Fig. 8).

CCL5, CCL4, and CCL3 chemokine belong to the CC family, also known as macrophage inflammatory protein1-beta (MIP-1beta). CCL5/RANTES chemokine is localized to chromosome 17 in humans and activates G-protein coupled receptor. Its main role is to engage leukocytes into inflammatory sites and canal. They are released by T-cells with the help of a particular cytokine. CCL4 is a chemoattractant for a variety of immune cells and has specificity for the CCR5 receptor (Huang and Levitz 2000). Its aggregation causes chronic inflammation and liver damage. They bind to G-protein coupled receptors CCR5 and CCR8 and are produced by monocytes, neutrophils, B cells, $\mathrm{T}$ cells, endothelial cells, fibroblasts, and epithelial cells. CCL3 is involved in acute inflammation and activation of granulocytes (category of white blood cells also known as polymorpho-nuclear leukocytes) (Chaplin 2010). CXCL2 and CXCL1 chemokine belong to the CXC family and are also known as macrophage inflammatory protein-2-alpha (MIP-2alpha). CXCL2 has a pro-inflammatory action, and it mobilizes cells by interacting with the CXCR2 chemokine receptor present on the cell surface. CXCL1 exerts a host immune response by engaging and activating neutrophils,

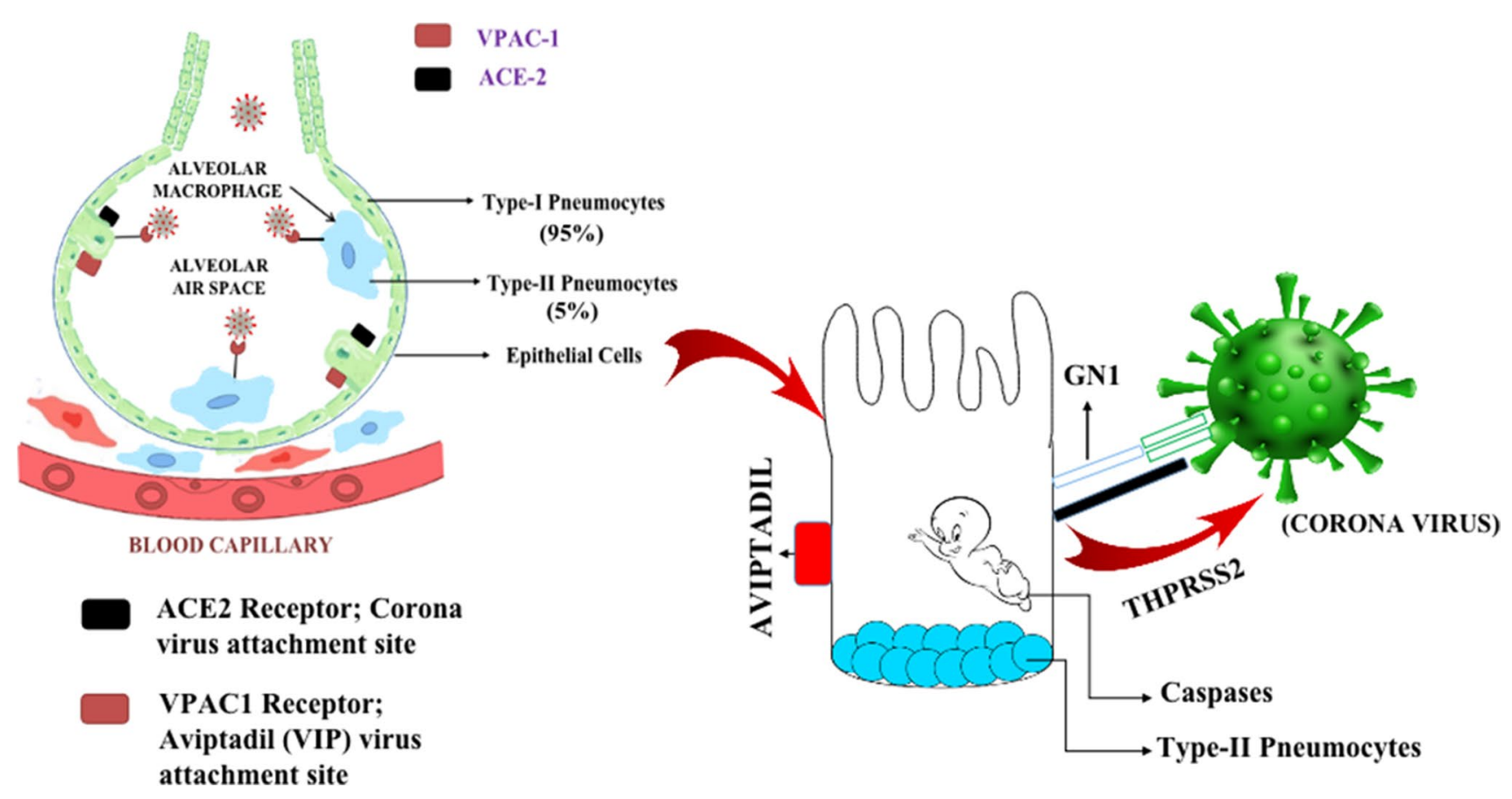

Fig. 8 Aviptadil protects type 2 pneumocytes by binding to VPAC-1 receptor and preventing the action of caspase induced by the coronavirus which also binds to the type II pneumocytes with the help of ACE-II receptor. Caspase instructs the cells to kill themselves promoting apoptosis 
whereas it also activates the release of proteases and reactive oxygen species (ROS) for microbe killing at the tissue site. It mediates its function by binding to the CXCR2 receptor and glycosaminoglycans (GAG) on endothelial and epithelial cells. Among these, CCL5, CCL4, and CCL3 cause an increment in several macrophages, monocytes, and $\mathrm{T}$ helper cells clouding to the site of infection as these are the activators of inflammatory bodies (Felsenstein et al. 2020; Temerozo et al. 2013). Similarly, CXCL2 and CXCL1 increase neutrophil aggregation. Aviptadil binds to macrophages or dendritic cells and inhibits the release of these chemokines, thereby reducing the accumulation of monocytes, neutrophils, and other immune cells. Aviptadil defends type 2 pneumocytes, induces bronchodilation, and supports the immune system (Sokol and Luster 2015). Once Aviptadil is linked to the NAIVE-T cell of the VIP1 receptor, the TH2 pathway is brought back, which is accompanied by triggering the $\mathrm{B}$ cell reaction, including the $\mathrm{TH} 2$ pathway along with CD8 cells. As a result of activation of cytotoxic cells, Aviptadil suppresses the TH1 pathway and promotes TREG (T regulatory pathway or immune balancing pathway or immunosuppressive pathway) and declines tumor necrosis factor (Flynn et al. 1998; Corthay 2009). Aviptadil reduces IL6 factor and RANTES secretion. The destructive immune response gets minimized, and the response towards the cell is also controlled. Hence, the overall immune system is balanced and further prevents initiation of cytokine storm (Tanaka et al. 2014).

\section{Clinical trials}

The clinical trial data of patients taking Aviptadil is showing rapid recovery in the cases of COVID-induced respiratory failure. Aviptadil blocks the replication of the SARSCOV2 virus within the lung cells (biospace.com 2020). It was observed that when the drug was administered to the patients on ventilation, they exhibited rapid improvement within 3 days only. The common cause of death due to COVID-19 is respiratory failure. Furthermore, some trial steps are still pending for different problems and doses of Aviptadil, respectively. The combined regimen with some other drugs is also being evaluated (health.economictimes. indiatimes.com 2020). According to the recent trial data, it can be stated that Aviptadil aids in a very rapid recovery. In Houston Methodist Hospital, a geriatric COVID positive case was reported with lung transplantation history, before the COVID test. The patient was manifested with a fatal immunological response, mediated by the rejection phase. In the rejection phase, there are lots of immunological parameters, like MHC (major histocompatibility complex), which were mismatched. The body attacks the foreign tissue and tries to destroy it (clinicaltrialsarena.com 2020). The main target is to minimize fatal antigen-antibody interaction. In a subject, with a history of renal failure, suffering from COVID-19, the trial reports depicted a strong negative impact due to other medications also as those medications were being contraindicated as per the medical status of that subject (Nicholson 2016). Experimentally, 3 infusions of Aviptadil or RLF-100 were administered to treat the respiratory failure when the subject was admitted to the ICU. Within $24 \mathrm{~h}$, the third infusion was given, and then it was observed that there was a significant improvement in oxygen saturation. Radiological status was also improved as the inflammation gradually curbed. More than $50 \%$ result of a partial fraction of oxygen was observed, as it was 146 before and 285.19 after administration of Aviptadil. Oxygen saturation (SP02) was 95 before medication and 98 after Aviptadil administration. After 1 week, the subject was discharged from ICU, and after getting such a good response, the medication was administered to 15 more patients, where the survival rate was reported to be elevated. The drug RLF100 was given to more patients who were suffering from respiratory failure, where rapid improvement was observed in patient (pharmaceutical-technology.com 2020). In the second case study, 45 patients were on ventilators suffering from respiratory failure. Meanwhile, no medication was effective for this condition, and no one was eligible for the randomized controlled trial. An open trial was conducted by the doctors informing the patients about the new drug to be injected, from which only twenty-one patients were selected for injecting Aviptadil drug and the rest twenty-four patients were examined with standard care as given before. Approximately 80 percent of patients survived and got recovered after 60 days of Aviptadil therapy, and 70 percent of patients got recovered with standard treatment. Observing such a huge rate of recovery, i.e., the survival rate of nine times more than the recovery rate of the patients, was a strong output. The study is still being conducted, and it is likely to be completed around December 2021 (clinicaltrials.gov 2021). Aviptadil has exhibited long time records of safety in segment 2 preliminaries for sarcoid, pulmonary fibrosis, bronchospasm, and ARDS. In this segment, 8 patients with intense ARDS have been handled with hiking quantity of VIP. As a result, seven patients were extubated and seen alive on the fifth day in a row, out of which six left the hospital, and only one patient died from the adverse cardiac event (Arondi et al. 2016). Under the European regulatory authority, five phase 2 trials of Aviptadil were conducted, showing that IV infusion of Aviptadil is well-tolerated among healthy volunteers. The adverse effect includes alterations in heart rate or ECG, pulse rate.

For several years in some ICUs, aviptadil has been used on a compounded basis with the belief that it protects life and improves function in pulmonary hypertension, ARDS, and acute lung injury (ALI) (clinicaltrials.gov 2020). A routine pharmacotherapy by Aviptadil 
was also observed in critical ICU patients. Essential end-points may be development in blood oxygenation level and reduced mortality. A clinical trial of Aviptadil in phase II/III remains underway. On the other hand, a placebo trial was done additionally to observe the supportive effect besides anti-SARS-CoV-2 action, to maintain proper physiology in COVID condition (prnewswire.com 2020) (Table 1).

\section{Future perspectives}

RLF-100 is a patented system of Aviptadil granted by the FDA in combination with phentolamine, which is anticipated to offer the opportunity for erectile dysfunction (ED). On corpora cavernosum and corpora spongiosum, it shows vasodilatory action. Thus, there are previous shreds of evidence which state that Aviptadil is free from troublesome side effects and has better delivery methods (clinicaltrials. gov 2020). It also improves muscle activity and blood flow in the gastrointestinal tract (Browning and Travagli 2014). Aviptadil promotes GIT motility along with lower esophageal sphincter relaxation, enhances water secretion in pancreatic juice, bile, and also increases the production of pepsinogen in the chief cells (Kilbinger and Weihrauch 1982), (urology.med.wayne.edu 2020). Aviptadil shows inotropic and chronotropic effects in CVS and optimizes the blood supply, which in turn increases the force of contraction and heart beats of the patient, with overall sound cardiac effect. Therefore, it can also be concluded that in future apart from infectious diseases, it will also have importance in CVS (Boyette and Manna 2020). In females, Aviptadil doubles vaginal lubrication and regulates prolactin secretion (Kariman 2020). On the other hand, Aviptadil or RLF-100 has anti-cytokine and anti-inflammatory properties. Preliminary studies have shown its protective function for alveolar type 2 cells and prevention of SARS-COV2 virus replication in lungs, thus limiting lung damage. Aviptadil was also granted by the FDA for acute respiratory distress syndrome and chronic lung disease (Sarkar et al. 2020). Low VIP concentrations are found in patients with idiopathic PAH, but there is a rise in VIP-mediated receptor expression. Substitution of chronic external VIP via an aerosol is beneficial for these patients. However, the evaluation of the role of VIP substitution is not yet done in PAH suffering patients, which is also essential to formulate it as a COVID therapy (Wu et al. 2011). Aviptadil has pulmonary and intrapulmonary selectivity, especially in chronic hypoxemia or lung disease. The first reported recovery was of a 54 years old man manifested with a lung transplant and then later developed a COVID-19 infection. Treatment with Aviptadil infusion shows recovery from COVID. On the other side, better than any other drug, Aviptadil regulates the immunological reaction in the body. Various studies indicate that the selectivity of Aviptadil is based on pulmonary vasodilatation assets, which are in turn linked to increased oxygenation and decreased pulmonary collapse. It is also predicted that Aviptadil will enter the market very soon (Lee and Bora 2020; healthwire.co 2020).

\section{Conclusion}

The rapid clinical improvement was seen in the first patient, treated with RLF-100 (Aviptadil). The hypothesis is that VIP defends AT-II cells, prevents cytokine storm, and increases oxygenation in a threatening lung. When the lungs are manifested with SARS-CoV-2 infection, VIP plays a critical role. Rapid recovery was reported in patients on ventilators and ECMO (extracorporeal membrane oxygenation), with various medical histories, after 3 days of FDA emergency treatment with RLF-100, with IND approval at multiple clinical sites. Aviptadil is the first vasoactive intestinal peptide that is being created to inhibit replication of the SARS-CoV-2 virus in the host cell including monocytes, as the first COVID-19 therapy. RLF-100 or Aviptadil is a synthetic human VIP that has also been patented. It is also granted with fast tracer designation. All the evident data, published based on clinical

Table 1 Clinical trials on Aviptadil

\begin{tabular}{|c|c|c|c|c|c|}
\hline S. No & Disease & Treatment & Date and month & Phases & Observation \\
\hline 1 & COVID-19 & $\begin{array}{l}\text { Drug: Aviptadil } 67 \mu \mathrm{g} \text { three times } \\
\text { a day for } 10 \text { days }\end{array}$ & August 2020 & Phase I & $\begin{array}{l}\text { Positive result in five days in mor- } \\
\text { tality rate, } \mathrm{PaO} 2, \mathrm{FiO} 2\end{array}$ \\
\hline 2 & Corona virus infection & $\begin{array}{c}\text { Drug of Aviptadil and drug of } \\
\text { placebo } 0.9 \% \mathrm{NaCl} \text { solution }\end{array}$ & March 2020 & Phase II & Ongoing research \\
\hline 3 & $\begin{array}{l}\text { Acute respiratory distress syn- } \\
\text { drome (ARDS) }\end{array}$ & $\begin{array}{l}\text { Drug Aviptadil (RLF100) or } \\
\text { placebo three times daily }\end{array}$ & $31 / 12 / 2020$ & Phase II & Data is under process \\
\hline 4 & $\begin{array}{l}\text { COVID-19 with respiratory } \\
\text { failure }\end{array}$ & $\begin{array}{l}\text { Drug Aviptadil through IV and } \\
\text { standard care } \\
\text { Drug: RLP100 (AVIPTADIL) }\end{array}$ & $28 / 02 / 2021$ & Phase II & Improvement in oxygen saturation \\
\hline 5 & Acute lung injury & $\begin{array}{l}\text { Drug of nebulized organization of } \\
\text { Aviptadil and placebo }\end{array}$ & August 2020 & $\begin{array}{l}\text { Phase II } \\
\text { Phase III }\end{array}$ & $\begin{array}{l}\text { Progress in several patients as well } \\
\text { as critical in } 28 \text { days }\end{array}$ \\
\hline
\end{tabular}


trials, seem to be very fruitful in defining a pharmacological guideline for COVID care. In recent clinical trials, the overall target result is that there is a tremendous improvement in life expectancy, by optimizing oxygenation and surveilling cytokine storm in COVID-19-induced respiratory failure.

Author contribution TM, TB, and BM: Conceived the study and wrote the first draft of the paper. SS1, AS, and SS2: Figure work. NS, JK, RK, and MD: Data compilation. LA and SB: Proof read.

Availability of data and materials Not applicable.

\section{Declarations}

Ethics approval Not applicable.

Consent to participate Not applicable.

Consent for publication All the authors have approved the manuscript for publication.

Competing interests The authors declare no competing interests.

\section{References}

Achilly NP (2016) Properties of VIP+ synapses in the suprachiasmatic nucleus highlight their role in circadian rhythm. J Neurophysiol 115(6):2701-2704. https://doi.org/10.1152/jn.00393.2015

AGG Mathioudakis (2021) Vasoactive intestinal peptide inhaled agonists: potential role in respiratory therapeutics [Internet]. PubMed Central (PMC). [cited 29 January2021]. Available from: https://www.ncbi.nlm.nih.gov/pmc/articles/PMC3738270/

Al-Chalabi M, Bass A, Alsalman I. Physiology, Prolactin [Internet]. Ncbi.nlm.nih.gov. 2020 [cited 22 November 2020]. Available from: https://www.ncbi.nlm.nih.gov/books/NBK507829/

Arondi S, Valsecchi A, Borghesi A, Monti S (2016) Pulmonary sarcoidosis presenting with acute respiratory distress syndrome. Ann Thorac Med. 11(1):79-81. https://doi.org/10.4103/18171737.164301

Astuti I, Ysrafil (2020) Severe acute respiratory syndrome coronavirus 2 (SARS-CoV-2): an overview of viral structure and host response. Diabetes Metab Syndr 14(4):407-412. https://doi.org/ 10.1016/j.dsx.2020.04.020

Azadzoi KM, Siroky MB (2010) Neurologic factors in female sexual function and dysfunction. Korean J Urol 51(7):443-449. https://doi.org/10.4111/kju.2010.51.7.443

Ban Y, Shigeyoshi Y, Okamura H (1997) Development of vasoactive intestinal peptide mRNA rhythm in the rat suprachiasmatic nucleus. J Neurosci 17(10):3920-3931. https://doi.org/10. 1523/JNEUROSCI.17-10-03920.1997

Behl T, Kaur I, Bungau S, Kumar A, Uddin MS, Kumar C, Pal G, Sahil, Shrivastava K, Zengin G, Arora S (2020) The dual impact of ACE2 in COVID-19 and ironical actions in geriatrics and pediatrics with possible therapeutic solutions. Life Sci. 257:118075. https://doi.org/10.1016/j.lfs.2020.118075

Bellinghausen I, Brand P, Böttcher I, Klostermann B, Knop J, Saloga J (2003) Production of interleukin-13 by human dendritic cells after stimulation with protein allergens is a key factor for induction of $\mathrm{T}$ helper 2 cytokines and is associated with activation of signal transducer and activator of transcription-6. Immunology 108(2):167-176. https://doi.org/10.1046/j.13652567.2003.01576.x

Benigni A, Corna D, Zoja C, Sonzogni A, Latini R, Salio M, Conti S, Rottoli D, Longaretti L, Cassis P, Morigi M, Coffman TM, Remuzzi G (2009) Disruption of the Ang II type 1 receptor promotes longevity in mice. J Clin Invest 119(3):524-530. https://doi.org/10.1172/JCI36703

Benigni A, Cassis P, Remuzzi G (2010) Angiotensin II revisited: new roles in inflammation, immunology and aging. EMBO Mol Med 2(7):247-257. https://doi.org/10.1002/emmm.201000080

Boone M, Deen PM (2008) Physiology and pathophysiology of the vasopressin-regulated renal water reabsorption. Pflugers Arch 456(6):1005-1024. https://doi.org/10.1007/s00424-008-0498-1

Bosch BJ, van der Zee R, de Haan CA, Rottier PJ (2003) The coronavirus spike protein is a class I virus fusion protein: structural and functional characterization of the fusion core complex. J Virol 77(16):8801-8811. https://doi.org/10.1128/jvi.77.16. $8801-8811.2003$

Boyette L, Manna B (2020) Physiology, Myocardial oxygen demand [Internet]. Ncbi.nlm.nih.gov. [cited22November2020].Available from: https://www.ncbi.nlm.nih.gov/books/NBK499897/

Brandt J, Mandiga P (2020) Histology, Alveolar Cells [Internet]. Ncbi.nlm.nih.gov. [cited 22 November 2020]. Available from: https://www.ncbi.nlm.nih.gov/books/NBK557542/

Brewster UC, Perazella MA (2004) The renin-angiotensin-aldosterone system and the kidney: effects on kidney disease. Am J Med 116(4):263-272. https://doi.org/10.1016/j.amjmed.2003. 09.034

Brosnahan SB, Jonkman AH, Kugler MC, Munger JS, Kaufman DA (2020) COVID-19 and respiratory system disorders: current knowledge, future clinical and translational research questions. ArteriosclerThrombVasc Biol 40(11):2586-2597. https://doi.org/ 10.1161/ATVBAHA.120.314515

Browning KN, Travagli RA (2014) Central nervous system control of gastrointestinal motility and secretion and modulation of gastrointestinal functions. Compr Physiol 4(4):1339-1368. https://doi. org/10.1002/cphy.c130055

Busnadiego I, Fernbach S, Pohl MO, Karakus U, Huber M, Trkola A, Stertz S, Hale BG (2020) Antiviral activity of type I, II, and III interferons counterbalances ACE2 inducibility and restricts SARS-CoV-2. mBio. 11(5):e01928-20. https://doi.org/10.1128/ mBio.01928-20

Cardani A, Boulton A, Kim TS, Braciale TJ (2017) Alveolar macrophages prevent lethal influenza pneumonia by inhibiting infection of type-1 alveolar epithelial cells. PLoS Pathog 13(1):e1006140. https://doi.org/10.1371/journal.ppat.1006140

Chaplin DD (2010) Overview of the immune response. J Allergy Clin Immunol 125(2 Suppl 2):S3-23. https://doi.org/10.1016/j.jaci. 2009.12.980

Chatila WM, Thomashow BM, Minai OA, Criner GJ, Make BJ (2008) Comorbidities in chronic obstructive pulmonary disease. Proc Am Thorac Soc 5(4):549-555. https://doi.org/10.1513/pats. 200709-148ET

Clarke NE, Turner AJ (2012) Angiotensin-converting enzyme 2: the first decade. Int J Hypertens 2012:307315. https://doi.org/10. 1155/2012/307315

Clinical trials in human medicines - European Medicines Agency [Internet]. EuropeanMedicines Agency. 2021 [cited 29 January 2021]. Available from:https://www.ema.europa.eu/en/humanregulatory/research-development/clinical-trials-human-medic ines

Clinicaltrials.gov (2021) Login to ClinicalTrials.gov PRS - ClinicalTrials.gov. [online] Available at: <https://clinicaltrials.gov/ct2/ manage-recs/register $>$ [Accessed 17 February 2021] 
Coperchini F, Chiovato L, Croce L, Magri F, Rotondi M (2020) The cytokine storm in COVID-19: an overview of the involvement of the chemokine/chemokine-receptor system. Cytokine Growth Factor Rev 53:25-32. https://doi.org/10.1016/j.cytogfr.2020.05. 003

Coronavirus (COVID-19) Update: FDA issues emergency use authorization for potential COVID-19 treatment [Internet]. U.S. Food and Drug Administration. 2021 [cited29 January 2021]. Available from: https://www.fda.gov/news-events/press-announceme nts/coronavirus-covid-19-update-fda-issues-emergency-useauthorization-potential-covid-19-treatment

Corthay A (2009) How do regulatory T cells work? Scand J Immunol 70(4):326-336. https://doi.org/10.1111/j.1365-3083.2009. 02308.x

Coutard B, Valle C, de Lamballerie X, Canard B, Seidah NG, Decroly E (2020) The spike glycoprotein of the new coronavirus 2019nCoV contains a furin-like cleavage site absent in $\mathrm{CoV}$ of the same clade. Antiviral Res 176:104742. https://doi.org/10.1016/j. antiviral.2020.104742

Couvineau A, Laburthe M (2012) VPAC receptors: structure, molecular pharmacology and interaction with accessory proteins. Br J Pharmacol 166(1):42-50. https://doi.org/10.1111/j.1476-5381. 2011.01676.x

Danilczyk U, Penninger JM (2006) Angiotensin-converting enzyme II in the heart and the kidney. Circ Res 98(4):463-471. https://doi. org/10.1161/01.RES.0000205761.22353.5f

Dasenbrook E (2020) Keep cystic fibrosis patients out of the hospital. Cleve Clin J Med. https://doi.org/10.3949/ccjm.87a.ccc005

Dérand R, Montoni A, Bulteau-Pignoux L, Janet T, Moreau B, Muller JM, Becq F (2004) Activation of VPAC1 receptors by VIP and PACAP-27 in human bronchial epithelial cells induces CFTRdependent chloride secretion. Br J Pharmacol 141(4):698-708. https://doi.org/10.1038/sj.bjp.0705597

Donoghue M, Hsieh F, Baronas E, Godbout K, Gosselin M, Stagliano N, Donovan M, Woolf B, Robison K, Jeyaseelan R, Breitbart RE, Acton S (2000) A novel angiotensin-converting enzyme-related carboxypeptidase (ACE2) converts angiotensin I to angiotensin 1-9. Circ Res 87(5):E1-9. https://doi.org/10.1161/01.res.87.5.e1

Du L, He Y, Zhou Y, Liu S, Zheng BJ, Jiang S (2009) The spike protein of SARS-CoV - a target for vaccine and therapeutic development. Nat Rev Microbiol 7(3):226-236. https://doi.org/10.1038/ nrmicro2090

Fehrenbach H (2001) Alveolar epithelial type II cell: defender of the alveolus revisited. Respir Res 2(1):33-46. https://doi.org/10. $1186 / \mathrm{rr} 36$

Felsenstein S, Herbert JA, McNamara PS, Hedrich CM (2020) COVID-19: Immunology and treatment options. Clin Immunol 215:108448. https://doi.org/10.1016/j.clim.2020.108448

Flynn S, Toellner KM, Raykundalia C, Goodall M, Lane P (1998) CD4 T cell cytokine differentiation: the B cell activation molecule, OX40 ligand, instructs CD4 T cells to express interleukin 4 and upregulates expression of the chemokine receptor, Blr-1. J Exp Med 188(2):297-304. https://doi.org/10.1084/jem. 188.2.297

Frieman M, Baric R (2008) Mechanisms of severe acute respiratory syndrome pathogenesis and innate immunomodulation. Microbiol Mol Biol Rev 72(4):672-85. https://doi.org/10.1128/ MMBR.00015-08 (Table of Contents)

Galanopoulos M, Doukatas A, Gazouli M (2020) Origin and genomic characteristics of SARS-CoV-2 and its interaction with angiotensin converting enzyme type 2 receptors, focusing on the gastrointestinal tract. World J Gastroenterol 26(41):6335-6345. https:// doi.org/10.3748/wjg.v26.i41.6335

Gheblawi M, Wang K, Viveiros A, Nguyen Q, Zhong JC, Turner AJ, Raizada MK, Grant MB, Oudit GY (2020) Angiotensin-Converting enzyme 2: SARS-CoV-2 receptor and regulator of the renin-angiotensin system: celebrating the 20th anniversary of the discovery of ACE2. Circ Res 126(10):1456-1474. https:// doi.org/10.1161/CIRCRESAHA.120.317015

Ghosh S, Das S, Mondal R, Abdullah S, Sultana S, Singh S, Sehgal S, Behl T (2021) A review on the effect of COVID-19 in type 2 asthma and its management. Int Immunopharmacol 91:107309. https://doi.org/10.1016/j.intimp.2020.107309

Gomez RA, Sequeira-Lopez MLS (2018) Renin cells in homeostasis, regeneration and immune defence mechanisms. Nat Rev Nephrol 14(4):231-245. https://doi.org/10.1038/nrneph.2017.186

Grant S, Lutz EM, McPhaden AR, Wadsworth RM (2006) Location and function of VPAC1, VPAC2 and NPR-C receptors in VIPinduced vasodilation of porcine basilar arteries. J Cereb Blood Flow Metab 26(1):58-67. https://doi.org/10.1038/sj.jcbfm.96001 63

Gu J, Korteweg C (2007) Pathology and pathogenesis of severe acute respiratory syndrome. Am J Pathol 170(4):1136-1147. https:// doi.org/10.2353/ajpath.2007.061088

Han S, Mallampalli RK (2015) The role of surfactant in lung disease and host defense against pulmonary infections. Ann Am Thorac Soc 12(5):765-774. https://doi.org/10.1513/AnnalsATS. 201411-507FR

Heurich A, Hofmann-Winkler H, Gierer S, Liepold T, Jahn O, Pöhlmann S (2014) TMPRSS2 and ADAM17 cleave ACE2 differentially and only proteolysis by TMPRSS2 augments entry driven by the severe acute respiratory syndrome coronavirus spike protein. J Virol 88(2):1293-1307. https://doi.org/10.1128/JVI. 02202-13

Hoffmann M, Kleine-Weber H, Schroeder S, Krüger N, Herrler T, Erichsen S, Schiergens TS, Herrler G, Wu NH, Nitsche A, Müller MA, Drosten C, Pöhlmann S (2020) SARS-CoV-2 cell entry depends on ACE2 and TMPRSS2 and is blocked by a clinically proven protease inhibitor. Cell 181(2):271-280.e8. https://doi. org/10.1016/j.cell.2020.02.052

Huang C, Levitz SM (2000) Stimulation of macrophage inflammatory protein-1alpha, macrophage inflammatory protein-1beta, and RANTES by Candida albicans and Cryptococcus neoformans in peripheral blood mononuclear cells from persons with and without human immunodeficiency virus infection. J Infect Dis 181(2):791-794. https://doi.org/10.1086/315250

[Internet] (2020a) [cited 22 November 2020]. Available from: https:// www.clinicaltrialsarena.com/news/neurorx-relief-aviptadil-data/

[Internet] (2020b) [cited 22 November 2020]. Available from: https:// www.pharmaceutical-technology.com/features/neurorx-covid19-respiratory-failure/

Inhaled Aviptadil for the prevention of COVID-19 related ARDS - full text view - ClinicalTrials.gov [Internet]. Clinicaltrials.gov. 2020 [cited 22 November 2020]. Available from: https://clinicaltrials. gov/ct2/show/NCT04536350

Inhaled Aviptadil for the treatment of moderate and severe COVID-19 - full text view - ClinicalTrials.gov [Internet]. Clinicaltrials.gov. 2020 [cited 22 November 2020]. Available from: https://clinicaltr ials.gov/ct2/show/NCT04360096

Intravenous Aviptadil for critical COVID-19 with respiratory failure - full text view- ClinicalTrials.gov [Internet]. Clinicaltrials.gov. 2021 [cited 29 January 2021]. Availablefrom: https://clinicaltr ials.gov/ct2/show/NCT04311697

Iwasaki M, Akiba Y, Kaunitz JD (2019) Recent advances in vasoactive intestinal peptide physiology and pathophysiology: focus on the gastrointestinal system. F1000Res 8:F1000 Faculty Rev-1629. https://doi.org/10.12688/f1000research.18039.1

Jia HP, Look DC, Shi L, Hickey M, Pewe L, Netland J, Farzan M, Wohlford-Lenane C, Perlman S, McCray PB Jr (2005) ACE2 receptor expression and severe acute respiratory syndrome coronavirus infection depend on differentiation of human airway 
epithelia. JVirol. 79(23):14614-21. https://doi.org/10.1128/JVI. 79.23.14614-14621.2005

Johnson ER, Matthay MA (2010) Acute lung injury: epidemiology, pathogenesis, and treatment. J Aerosol Med Pulm Drug Deliv 23(4):243-252. https://doi.org/10.1089/jamp.2009.0775

Kany S, Vollrath JT, Relja B (2019) Cytokines in inflammatory disease. Int J Mol Sci 20(23):6008. https://doi.org/10.3390/ijms20236008

Kariman NS (2020) The diagnostic power of cervico-vaginal fluid prolactin in the diagnosis of premature rupture of membranes [Internet]. PubMed Central (PMC). [cited 22 November 2020]. Available from: https:/www.ncbi.nlm.nih.gov/pmc/articles/ PMC3482326/

Kia'i N, Bajaj T (2020) Histology, respiratory epithelium. [Updated 2020 Jul 3]. In: StatPearls [Internet]. StatPearls Publishing, Treasure Island. Available from: https://www.ncbi.nlm.nih.gov/ books/NBK541061/

Kilbinger H, Weihrauch TR (1982) Drugs increasing gastrointestinal motility. Pharmacology 25(2):61-72. https://doi.org/10.1159/ 000137725

Knudsen L, Ochs M (2018) The micromechanics of lung alveoli: structure and function of surfactant and tissue components. Histochem Cell Biol. 150(6):661-676. https://doi.org/10.1007/ s00418-018-1747-9

Lee C, Bora V (2020) Anesthesia Monitoring Of Mixed Venous Saturation [Internet]. Ncbi.nlm.nih.gov. [cited 22 November 2020]. Available from: https://www.ncbi.nlm.nih.gov/books/NBK53 9835/

Lefebvre H, Duparc C, Naccache A, Lopez AG, Castanet M, Louiset E (2019) Paracrine regulation of aldosterone secretion in physiological and pathophysiological conditions. VitamHorm 109:303-339. https://doi.org/10.1016/bs.vh.2018.10.001

LeMessurier KS, Tiwary M, Morin NP, Samarasinghe AE (2020) Respiratory barrier as a safeguard and regulator of defense against influenza A virus and streptococcus pneumoniae. Front Immunol 4(11):3. https://doi.org/10.3389/fimmu.2020.00003

Leuchte HH, Baezner C, Baumgartner RA, Bevec D, Bacher G, Neurohr C, Behr J (2008) Inhalation of vasoactive intestinal peptide in pulmonary hypertension. Eur Respir J 32(5):1289-1294. https://doi.org/10.1183/09031936.00050008

Lewis JF, Jobe AH (1993) Surfactant and the adult respiratory distress syndrome. Am Rev Respir Dis 147(1):218-233. https://doi.org/ 10.1164/ajrccm/147.1.218 (Erratum in: Am Rev Respir Dis 1993 Apr;147(4):following 1068)

Li X, Ma X (2020) Acute respiratory failure in COVID-19: is it \&quot;typical\&quot; ARDS? Crit Care 24(1):198. https://doi. org/10.1186/s13054-020-02911-9

Lindén A, Hansson L, Andersson A, Palmqvist M, Arvidsson P, Löfdahl CG, Larsson P, Lötvall J (2003) Bronchodilation by an inhaled VPAC(2) receptor agonist in patients with stable asthma. Thorax 58(3):217-221. https://doi.org/10.1136/thorax.58.3.217

Lisi L, Lacal PM, Barbaccia ML, Graziani G (2020) Approaching coronavirus disease 2019: Mechanisms of action of repurposed drugs with potential activity against SARS-CoV-2. Biochem Pharmacol 180:114169. https://doi.org/10.1016/j.bcp.2020.114169

Lodish H, Berk A, Zipursky SL, et al (2000) Molecular Cell Biology. 4th edition. New York: W. H. Freeman. Section 6.3, Viruses: structure, function, and uses. Available from: ://www.ncbi.nlm. nih.gov/books/NBK21523/

Loiseau C, Doumbo OK, Traore B, Brady JL, Proietti C, de Sousa KP, Crompton PD, Doolan DL (2020) A novel population of memory-activated natural killer cells associated with low parasitaemia in Plasmodium falciparum-exposed sickle-cell trait children. Clin Trans1 Immunol 9(4):e1125. https://doi.org/10.1002/cti2.1125

Lungs and Respiratory System (for Parents) - Nemours KidsHealth [Internet]. Kidshealth.org. 2020 [cited 22 November 2020]. Available from: https://kidshealth.org/en/parents/lungs.html
Lythgoe MP, Middleton P (2020) Ongoing clinical trials for the management of the COVID-19 pandemic. Trends Pharmacol Sci 41(6):363-382. https://doi.org/10.1016/j.tips.2020.03.006

Mariappan V, S R Rao, Balakrishna Pillai A. Angiotensin-converting enzyme 2: a protective factor in regulating disease virulence of SARS-COV-2. IUBMB Life. 2020;72(12):2533-2545. doi: https://doi.org/10.1002/iub.2391.

Martínez C, Juarranz Y, Gutiérrez-Cañas I, Carrión M, Pérez-García S, Villanueva-Romero R, Castro D, Lamana A, Mellado M, González-Álvaro I, Gomariz RP (2019) A clinical approach for the use of VIP axis in inflammatory and autoimmune diseases. Int J Mol Sci 21(1):65. https://doi.org/10.3390/ijms21010065

Mason RJ (2020) Pathogenesis of COVID-19 from a cell biology perspective. Eur Respir J 55(4):2000607. https://doi.org/10.1183/ 13993003.00607-2020

Mathioudakis A, Chatzimavridou-Grigoriadou V, Evangelopoulou E, Mathioudakis G (2013) Vasoactive intestinal peptide inhaled agonists: potential role in respiratory therapeutics. Hippokratia 17(1):12-16

Matthay MA, Zemans RL, Zimmerman GA, Arabi YM, Beitler JR, Mercat A, Herridge M, Randolph AG, Calfee CS (2019) Acute respiratory distress syndrome. Nat Rev Dis Prim 5(1):18. https:// doi.org/10.1038/s41572-019-0069-0

McBride R, van Zyl M, Fielding BC (2014) The coronavirus nucleocapsid is a multifunctional protein. Viruses 6(8):2991-3018. https://doi.org/10.3390/v6082991

McIlwain DR, Berger T, Mak TW (2013) Caspase functions in cell death and disease. Cold Spring HarbPerspect Biol 5(4):a008656. https://doi.org/10.1101/cshperspect.a008656 (Erratum in: Cold Spring HarbPerspect Biol. 2015 Apr;7(4). . doi: 10.1101/cshperspect.a026716)

Merad M, Martin JC (2020) Pathological inflammation in patients with COVID-19: a key role for monocytes and macrophages. Nat Rev Immunol. 20(6):355-362. https://doi.org/10.1038/s41577-0200331-4 (Erratum in: Nat Rev Immunol. 2020 Jun 2)

Moody TW, Walters J, Casibang M, Zia F, Gozes Y (2000) VPAC1 receptors and lung cancer. Ann N Y Acad Sci 921:26-32. https:// doi.org/10.1111/j.1749-6632.2000.tb06947.x

Morrell NW, Archer SL, Defelice A, Evans S, Fiszman M, Martin T, Saulnier M, Rabinovitch M, Schermuly R, Stewart D, Truebel H, Walker G, Stenmark KR (2013) Anticipated classes of new medications and molecular targets for pulmonary arterial hypertension. Pulm Circ 3(1):226-244. https://doi.org/10.4103/ 2045-8932.109940

Nehme A, Zouein FA, Zayeri ZD, Zibara K (2019) An update on the tissue renin angiotensin system and its role in physiology and pathology. J Cardiovasc Dev Dis 6(2):14. https://doi.org/10.3390/ jcdd6020014.PMID:30934934;PMCID:PMC6617132

Neuman BW, Kiss G, Kunding AH, Bhella D, Baksh MF, Connelly S, Droese B, Klaus JP, Makino S, Sawicki SG, Siddell SG, Stamou DG, Wilson IA, Kuhn P, Buchmeier MJ (2011) A structural analysis of $\mathrm{M}$ protein in coronavirus assembly and morphology. J Struct Biol 174(1):11-22. https://doi.org/10. 1016/j.jsb.2010.11.021

NeuroRx I (2020) RLF-100 (aviptadil) clinical trial showed rapid recovery from respiratory failure and inhibition of coronavirus replication in human lung cells [Internet]. Prnewswire. com. [cited 22 November 2020]. Available from: https://www. prnewswire.com/news-releases/rlf-100-aviptadil-clinical-trial-showed-rapid-recovery-from-respiratory-failure-and-inhib ition-of-coronavirus-replication-in-human-lung-cells-30110 4384.html

New drug RLF-100 shows dramatic recovery in Covid-19 patients suffering respiratory failure - ET HealthWorld [Internet]. ETHealthworld.com. 2020 [cited 22 November 2020]. Available from: https://health.economictimes.indiatimes.com/news/pharma/ 
new-drug-rlf-100-shows-dramatic-recovery-in-covid-19-patie nts-suffering-respiratory-failure/77390990

New drug RLF-100 shows rapid recovery in critically ill coronavirus patients I HealthWire [Internet]. Healthwire.co. 2020 [cited 22 November 2020]. Available from: https://www.healthwire.co/ new-drug-rlf-100-shows-rapid-recovery-in-critically-ill-coron avirus-patients/amp/\#aoh $=16060620333471 \&$ referrer $=\mathrm{https} \%$ $3 \mathrm{~A} \% 2 \mathrm{~F} \% 2 \mathrm{Fwww}$.google.com\&amp_tf=From $\% 20 \% 251 \% 24 \mathrm{~s}$

Nicholson LB (2016) The immune system. Essays Biochem 60(3):275301. https://doi.org/10.1042/EBC20160017

Nita M, Grzybowski A (2016) The role of the reactive oxygen species and oxidative stress in the pathomechanism of the agerelated ocular diseases and other pathologies of the anterior and posterior eye segments in adults. Oxid Med Cell Longev 2016:3164734. https://doi.org/10.1155/2016/3164734

Parrish AB, Freel CD, Kornbluth S (2013) Cellular mechanisms controlling caspase activation and function. Cold Spring HarbPerspect Biol 5(6):a008672. https://doi.org/10.1101/cshperspect. a008672

Patel VB, Zhong JC, Grant MB, Oudit GY (2016) Role of the ACE2/ Angiotensin 1-7 axis of the renin-angiotensin system in heart failure. Circ Res 118(8):1313-1326. https://doi.org/10.1161/ CIRCRESAHA.116.307708

Paul S, Lal G (2017) The molecular mechanism of natural killer cells function and its importance in cancer immunotherapy. Front Immunol 13(8):1124. https://doi.org/10.3389/fimmu.2017.01124

Pendergrass KD, Gwathmey TM, Michalek RD, Grayson JM, Chappell MC (2009) The angiotensin II-AT1 receptor stimulates reactive oxygen species within the cell nucleus. Biochem Biophys Res Commun 384(2):149-154. https://doi.org/10.1016/j.bbrc.2009. 04.126

Persson PB (2003) Renin: origin, secretion and synthesis. J Physiol 552(Pt 3):667-671. https://doi.org/10.1113/jphysiol.2003. 049890

Peti-Peterdi J, Harris RC (2010) Macula densa sensing and signaling mechanisms of renin release. J Am Soc Nephrol 21(7):10931096. https://doi.org/10.1681/ASN.2009070759

Petkov V, Mosgoeller W, Ziesche R, Raderer M, Stiebellehner L, Vonbank K, Funk GC, Hamilton G, Novotny C, Burian B, Block LH (2003) Vasoactive intestinal peptide as a new drug for treatment of primary pulmonary hypertension. J Clin Invest 111(9):13391346. https://doi.org/10.1172/JCI17500

Poduri R, Joshi G, Jagadeesh G (2020) Drugs targeting various stages of the SARS-CoV-2 life cycle: exploring promising drugs for the treatment of Covid-19. Cell Signal 74:109721. https://doi.org/10. 1016/j.cellsig.2020.109721

Prasse A, Zissel G, Lützen N, Schupp J, Schmiedlin R, Gonzalez-Rey E, Rensing-Ehl A, Bacher G, Cavalli V, Bevec D, Delgado M, Müller-Quernheim J (2010) Inhaled vasoactive intestinal peptide exerts immunoregulatory effects in sarcoidosis. Am J Respir Crit Care Med 182(4):540-548. https://doi.org/10.1164/rccm. 200909-14510C

Qureshi H, Sharafkhaneh A, Hanania NA (2014) Chronic obstructive pulmonary disease exacerbations: latest evidence and clinical implications. Ther Adv Chronic Dis 5(5):212-227. https://doi. org/10.1177/2040622314532862

RESPIRATION SYSTEM [Internet] (2020) Letstalkacademy.com. [cited 22 November 2020]. Available from: https://www.letst alkacademy.com/publication/read/RESPIRATION-SYSTEM

RLF-100 (aviptadil) clinical trial showed rapid recovery from respiratory failure and inhibition of coronavirus replication in human lung cells | BioSpace [Internet]. BioSpace. 2020 [cited 22 November 2020]. Available from: https://www.biospace.com/ article/releases/rlf-100-aviptadil-clinical-trial-showed-rapidrecovery-from-respiratory-failure-and-inhibition-of-coronavirus-replication-in-human-lung-cells/
Robert R, Kentish-Barnes N, Boyer A et al (2020) Ethical dilemmas due to the Covid-19 pandemic. Ann Intensive Care 10:84. https:// doi.org/10.1186/s13613-020-00702-7

Ruch TR, Machamer CE (2012) The coronavirus E protein: assembly and beyond. Viruses 4(3):363-382. https://doi.org/10.3390/ v4030363

Saint-Criq V, Gray MA (2017) Role of CFTR in epithelial physiology. Cell Mol Life Sci 74(1):93-115. https://doi.org/10.1007/ s00018-016-2391-y

Sarkar C, Mondal M, Torequl Islam M, Martorell M, Docea AO, Maroyi A, Sharifi-Rad J, Calina D (2020) Potential therapeutic options for COVID-19: current status, challenges, and future perspectives. Front Pharmacol 15(11):572870. https://doi.org/ 10.3389/fphar.2020.572870

Scavone C, Brusco S, Bertini M, Sportiello L, Rafaniello C, Zoccoli A, Berrino L, Racagni G, Rossi F, Capuano A (2020) Current pharmacological treatments for COVID-19: What's next? Br J Pharmacol 177(21):4813-4824. https://doi.org/10.1111/bph.15072

Sexual Dysfunction [Internet]. (2020) Urology. [cited 22 November 2020]. Available from: https://urology.med.wayne.edu/impot ence-sexual

Shen LW, Mao HJ, Wu YL, Tanaka Y, Zhang W (2017) TMPRSS2: a potential target for treatment of influenza virus and coronavirus infections. Biochimie 142:1-10. https://doi.org/10.1016/j.biochi. 2017.07.016

Simmons G, Zmora P, Gierer S, Heurich A, Pöhlmann S (2013) Proteolytic activation of the SARS-coronavirus spike protein: cutting enzymes at the cutting edge of antiviral research. Antiviral Res 100(3):605-614. https://doi.org/10.1016/j.antiviral.2013.09.028

Singh AG, Chaturvedi P (2020) Clinical trials during COVID-19. Head Neck 42(7):1516-1518. https://doi.org/10.1002/hed.26223

Singh P, Tripathi MK, Yasir M, Khare R, Tripathi MK, Shrivastava R (2020) Potential inhibitors for SARS-CoV-2 and functional food components as nutritional supplement for COVID-19: a review. Plant Foods Hum Nutr 75(4):458-466. https://doi.org/10.1007/ s11130-020-00861-9

Sokol CL, Luster AD (2015) The chemokine system in innate immunity. Cold Spring Harb Perspect Biol 7(5):a016303. https://doi. org/10.1101/cshperspect.a016303

Sparks MA, Crowley SD, Gurley SB, Mirotsou M, Coffman TM (2014) Classical renin-angiotensin system in kidney physiology. Compr Physiol 4(3):1201-1228. https://doi.org/10.1002/cphy.c130040

Spencer LA, Weller PF (2010) Eosinophils and Th2 immunity: contemporary insights. Immunol Cell Biol. 88(3):250-6. https://doi. org/10.1038/icb.2009.115

Steers W (2020) Pharmacologic treatment of erectile dysfunction [Internet]. PubMed Central (PMC). [cited 22 November 2020]. Available from: https://www.ncbi.nlm.nih.gov/pmc/articles/ PMC1476024/

Stomach, Gallbladder and Pancreas I Interactive Anatomy Guide [Internet]. Innerbody. 2020 [cited 22 November 2020]. Available from: https://www.innerbody.com/image/dige02.html

Tanaka T, Narazaki M, Kishimoto T (2014) IL-6 in inflammation, immunity, and disease. Cold Spring Harb Perspect Biol 6(10):a016295. https://doi.org/10.1101/cshperspect.a016295

Tang T, Bidon M, Jaimes JA, Whittaker GR, Daniel S (2020) Coronavirus membrane fusion mechanism offers a potential target for antiviral development. Antiviral Res 178:104792. https://doi.org/ 10.1016/j.antiviral.2020.104792

Temerozo JR, Joaquim R, Regis EG, Savino W, Bou-Habib DC (2013) Macrophage resistance to HIV-1 infection is enhanced by the neuropeptides VIP and PACAP. PLoS ONE 8(6):e67701. https:// doi.org/10.1371/journal.pone.0067701

Thunders M, Delahunt B (2020) Gene of the month: TMPRSS2 (transmembrane serine protease 2). J Clin Pathol 73(12):773-776. https://doi.org/10.1136/jclinpath-2020-206987 
Topham NJ, Hewitt EW (2009) Natural killer cell cytotoxicity: how do they pull the trigger? Immunology 128(1):7-15. https://doi.org/ 10.1111/j.1365-2567.2009.03123.x

Type I Pneumocyte - an overview I ScienceDirect Topics [Internet]. Sciencedirect.com. 2020 [cited 22 November 2020]. Available from: https://www.sciencedirect.com/topics/biochemistry-genet ics-and-molecular-biology/type-i-pneumocyte

Vivier E, Raulet DH, Moretta A, Caligiuri MA, Zitvogel L, Lanier LL, Yokoyama WM, Ugolini S (2011) Innate or adaptive immunity? The example of natural killer cells. Science 331(6013):44-49. https://doi.org/10.1126/science.1198687

Wei B, Sheng LC (2018) Changes in Th1/Th2-producing cytokines during acute exacerbation chronic obstructive pulmonary disease. J Int Med Res 46(9):3890-3902. https://doi.org/10.1177/ 0300060518781642

Wu D, Lee D, Sung YK (2011) Prospect of vasoactive intestinal peptide therapy for COPD/PAH and asthma: a review. Respir Res 12(1):45. https://doi.org/10.1186/1465-9921-12-45

Wu J, Deng W, Li S, Yang X (2020) Advances in research on ACE2 as a receptor for 2019-nCoV. Cell Mol Life Sci 11:1-14. https:// doi.org/10.1007/s00018-020-03611-x
Zhang JM, An J (2007) Cytokines, inflammation, and pain. Int Anesthesiol Clin. 45(2):27-37. https://doi.org/10.1097/AIA.0b013 e318034194e

Zhang H, Penninger JM, Li Y, Zhong N, Slutsky AS (2020) Angiotensin-converting enzyme 2 (ACE2) as a SARS-CoV-2 receptor: molecular mechanisms and potential therapeutic target. Intensive Care Med 46(4):586-590. https://doi.org/10.1007/ s00134-020-05985-9

Zhao CZ, Fang XC, Wang D, Tang FD, Wang XD (2010) Involvement of type II pneumocytes in the pathogenesis of chronic obstructive pulmonary disease. Respir Med 104(10):1391-1395. https://doi. org/10.1016/j.rmed.2010.06.018

Zhou Y, Vedantham P, Lu K, Agudelo J, Carrion R Jr, Nunneley JW, Barnard D, Pöhlmann S, McKerrow JH, Renslo AR, Simmons G (2015) Protease inhibitors targeting coronavirus and filovirus entry. Antiviral Res 116:76-84. https://doi.org/10.1016/j.antiv iral.2015.01.011

Publisher's note Springer Nature remains neutral with regard to jurisdictional claims in published maps and institutional affiliations. 